\title{
New aquatic Oniscidea (Crustacea: Isopoda) from groundwater calcretes of Western Australia
}

\author{
Stefano Taiti ${ }^{1}$ and William F. Humphreys ${ }^{2}$ \\ ${ }^{1}$ Centro di Studio per la Faunistica ed Ecologia Tropicali del Consiglio Nazionale delle Ricerche, \\ Via Romana 17, 50125 Firenze, Italy - e-mail: taiti@fi.cnr.it \\ ${ }^{2}$ Western Australian Museum of Natural Science, Francis Street, Perth, \\ Western Australia 6000, Australia - e-mail: bill.humphreys@museum.wa.gov.au
}

\begin{abstract}
Three blind new species of Haloniscus Chilton (Scyphacidae s.l.) from groundwater calcretes in Western Australia are described: H. tomentosus, $H$. longiantennatus and $H$. stilifer. A diagnosis of the genus and a key to the species are provided, and its distribution is briefly discussed. Haloniscus stepheni Nicholls and Barnes, is redescribed and transferred to the genus Andricophiloscia Vandel in the family Philosciidae. A further new blind philosciid species collected in the same calcrete system as $H$. longiantennatus and $H$. stilifer is described and tentatively ascribed to the genus Andricophiloscia (A. pedisetosa).
\end{abstract}

\section{INTRODUCTION}

Diverse stygal communities have been recently found to inhabit the groundwater calcretes of arid Western Australia. The calcretes are associated with the palaeodrainage channels of the Pilbara and Yilgarn cratons and their associated orogens which together form the "Western Shield" of Australia (Beard, 1998). These areas have not been inundated by the sea since at least the Palaeozoic (see Humphreys, 1999). Information on the groundwater calcretes and the aquifers may be found in Poore and Humphreys (1998) and Humphreys (1999, 2001). Details of the aquifers and hydrogeochemistry of the Yilgarn palaeodrainage channels is summarised in Watts and Humphreys (1999, 2000) and the distribution of groundwater calcretes in Australia is given in Humphreys (1999: figure 3). To date, each discrete area of groundwater calcrete in the Yilgarn and the Pilbara has yielded a different fauna (Humphreys, 1999, 2001; Watts and Humphreys, 1999, 2000, unpublished data).

Among the fauna collected in calcrete aquifers in the Murchison and Northern Goldfields regions, several specimens of terrestrial isopods have been found belonging to three new species in the genus Haloniscus Chilton, 1920 and one new species of Philosciidae, tentatively included in the genus Andricophiloscia Vandel, 1973.

To date, Haloniscus included three species: $H$. searlei Chilton, 1920, H. stepheni Nicholls and Barnes, 1926 and H. anophthalmus Taiti, Ferrara and Iliffe, 1995. Haloniscus searlei and $H$. anophthalmus are aquatic forms, while Haloniscus stepheni is a terrestrial form collected under logs by the bank of
Kokatea Creek, near Tenindewa, Western Australia (Nicholls and Barnes, 1926). Re-examination of the syntypes of $H$. stepheni, together with new material collected from the type locality, revealed that this species does not belong to the genus Haloniscus (Scyphacidae s.l., see Taiti et al., 1995) but to the genus Andricophiloscia (Philosciidae).

\section{MATERIALS AND METHODS}

Stygofauna was sampled using haul nets $(250 \mu \mathrm{m}$ mesh) from unequipped bore holes that have been drilled for piezometers, mineral exploration or water abstraction. The water quality was determined as per Watts and Humphreys (2000).

The specimens were recorded from fresh and saline waters in the inland draining Carey palaeodrainage channel and from the Murchison system that drains towards the Indian Ocean (Watts and Humphreys, 1999, 2000) (Figure 1); Haloniscus has not been recorded from the Pilbara. The physico-chemical data available are given in Table 1.

Stygofauna associated with Haloniscus include: from northeast Lake Way - Bathynellacea (Syncarida), Cyclopoidea and Harpacticoidea (Copepoda), Ostracoda, Amphipoda, Tjirtudessus hahni Watts and Humphreys (Coleoptera: Dytiscidae), Nirridessus morgani Watts and Humphreys (Dytiscidae); from Austin Downs and Cue - Cyclopoidea and Harpacticoidea (Copepoda), Candonidae (Ostracoda: Podocopida), Amphipoda, Nirridessus cueensis Watts and Humphreys (Dytiscidae), Tjirtudessus magnificus Watts and Humphreys (Dytiscidae). 
Table 1 Physico-chemical characteristics of sites from which Haloniscus was recorded. For plotted profiles see Watts and Humphreys (2000: figure 39).

\begin{tabular}{|c|c|c|c|c|c|c|c|c|}
\hline Site & $\begin{array}{l}\text { 'Sample } \\
\text { depth (m) }\end{array}$ & $\begin{array}{l}\text { Salinity } \\
\mathrm{g} \mathrm{L}^{-}\end{array}$ & $\begin{array}{c}\text { Temperature } \\
{ }^{\circ} \mathrm{C}\end{array}$ & $\begin{array}{l}\text { Dissol } \\
\% \text { sat }\end{array}$ & $\begin{array}{l}\text { ved } \mathrm{O}^{2} \\
\mathrm{mg} \mathrm{L}^{-1}\end{array}$ & pH & $\begin{array}{l}{ }^{2} \text { Depth to } \\
\text { water }(\mathrm{m})\end{array}$ & $\begin{array}{l}{ }^{2} \text { Depth of } \\
\text { water }(\mathrm{m})\end{array}$ \\
\hline Abandoned Cue town bore & 0 & 5 & 25 & 50.5 & 3.9 & - & 4 & 0.5 \\
\hline NE Lake Way site 264 & $\begin{array}{l}- \\
0 \\
0.5 \\
1 \\
2 \\
4 \\
8\end{array}$ & $\begin{array}{l}20.2 \\
23.4 \\
23.8 \\
25.4 \\
27.3 \\
32.3 \\
40.7\end{array}$ & $\begin{array}{l}25 \\
24.8 \\
24.9 \\
25.2 \\
25.2 \\
24.6 \\
24.3\end{array}$ & $\begin{array}{l}49 \\
28 \\
- \\
- \\
- \\
- \\
-\end{array}$ & $\begin{array}{l}3.8 \\
2.2 \\
- \\
- \\
- \\
- \\
-\end{array}$ & $\begin{array}{l}8.4 \\
7.6 \\
- \\
- \\
- \\
- \\
-\end{array}$ & $\begin{array}{l}- \\
- \\
- \\
-\end{array}$ & $\begin{array}{l}- \\
- \\
- \\
-\end{array}$ \\
\hline NE Lake Way site 284 & 0 & 4.5 & 25.7 & 86 & 6.6 & 7.6 & 4 & 1.6 \\
\hline NE Lake Way site 286 & $\begin{array}{l}0 \\
0.5 \\
1 \\
2 \\
4 \\
8\end{array}$ & $\begin{array}{l}19.8 \\
20.1 \\
20.7 \\
23 \\
32.6 \\
40.5\end{array}$ & $\begin{array}{l}24.2 \\
24.4 \\
24.6 \\
24.2 \\
23.7 \\
23.2\end{array}$ & $\begin{array}{l}23 \\
- \\
- \\
- \\
- \\
-\end{array}$ & $\begin{array}{l}1.8 \\
- \\
- \\
- \\
- \\
-\end{array}$ & $\begin{array}{l}- \\
- \\
- \\
- \\
-\end{array}$ & $\begin{array}{l}2 \\
- \\
- \\
- \\
- \\
-\end{array}$ & $\begin{array}{l}20 \\
- \\
- \\
- \\
- \\
-\end{array}$ \\
\hline
\end{tabular}

From the groundwater surface.

2 Depth approximate.

The "Haloniscus stepheni" samples were all taken from the banks of Kockatea Gully at Nicholls and Barnes' (1926) original collection site for this species and from one location downstream at Byrons Crossing. The creek was flowing and had recently been in spate, at which time some of the collection sites would have been submerged. All specimens were collected from beneath timber or logs, as found by Nicholls and Barnes (1926), and all the isopods were in contact with the underlying sulphurous black mud. Isopods collected from higher up the banks were Laevophiloscia yalgoonensis Wahrberg, 1922 (Philosciidae). The general appearance of the site corresponds closely with the description by Nicholls and Barnes (1926), but no burrows were associated with the specimens.

The specimens examined are deposited in the Western Australian Museum, Perth (WAM) and in the Museo Zoologico 'La Specola' dell'Università, Florence (MZUF). BES denotes field numbers of the Biospeleology collection at WAM.

\section{SYSTEMATICS}

\section{Family Scyphacidae}

\section{Genus Haloniscus Chilton, 1920}

\section{Type Species}

Haloniscus searlei Chilton, 1920, by monotypy.

\section{Diagnosis}

Body elongated with pleon slightly narrower than pereon. Cephalon with small rounded lateral lobes not protruding frontward; supra-antennal line usually present (missing in $H$. anophthalmus); no frontal line. Pereonites with no noduli laterales and no visible gland pores. Pleon epimera with posterior points, more or less reduced, visible in dorsal view. Antennule of three articles with some aesthetascs at apex. Antennal flagellum of three articles with short apical organ. Molar penicil of mandible dichotomised, consisting of a tuft of plumose setae. Outer branch of maxillule with $4+6$ large teeth all with simple apex, and a flagelliform seta among the outer group of teeth; inner branch with two subequal penicils and no posterior point. Endite of maxilliped setose with a large penicil on medial corner; palp with medial tuft of setae inserted on a rounded tubercle and a distinct suture distally to that. Pereopods with flagelliform dactylar and ungual seta. Pereopod 1 with cleaning device for antennae more or less developed. Exopods of pleopods of right and left side overlapping medially, with no respiratory structures and with a marginal fringe of long setae (sometimes absent on pleopod 1). Uropod with protopod flattened, often enlarged; outer margin of protopod and exopod not grooved.

\section{Remarks}

Some of the characters included in the present diagnosis have not previously been described in some species, i.e. the large penicil on the medial corner of the maxillipedal endite in $H$. searlei [see description by Chilton (1920) and redescription by Williams (1970)], the suture distal to the medial tuft of setae on the maxillipedal palp in $H$. anophthalmus [see description in Taiti et al. (1995)], and the cleaning device on pereopod 1 in both these species. 


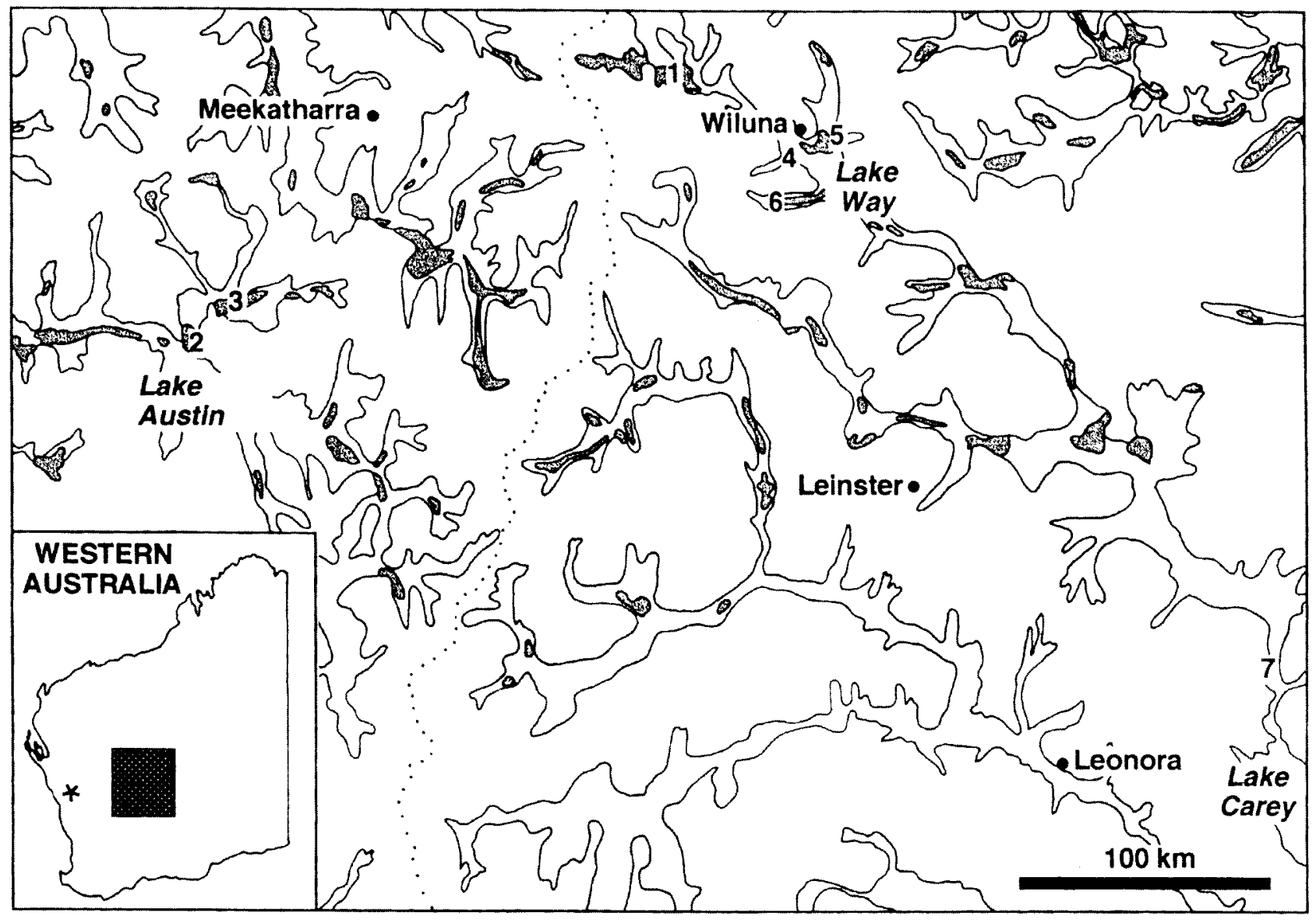

Figure 1 Map of Western Australia with localities of collections. Groundwater calcrete deposits (shaded) are shown in the palaeodrainage channels (solid lines). The dotted line denotes the surface drainage divide (Beard 1998); inland drainage to the east, Indian Ocean drainage to the west. The numerals denote discrete areas of calcrete that have been sampled (sites reported here bold): 1, Paroo; 2, Austin Downs; 3, Cue ; 4, Lake Violet; 5, North-east Lake Way; 6, Hinkler Well; 7, Mount Windarra. On the Western Australia map * denotes Kockatea Gully, Tenindewa, the collection site of Andricophiloscia stepheni (Nicholls and Barnes, 1926).

Re-examination of specimens of $H$. searlei from Lake Keilambete, Victoria, Australia and of paratypes of $H$. anoththalmus in the collections of MZUF has shown that these characters are present also in these species.

Haloniscus was originally included in the family Oniscidae s.l. by Chilton (1920) and, with some doubts, by Williams (1970), while Green (in Williams, 1970: 312) states that "the genus falls between the sub-families Schyphacinae [now the family Scyphacidae] and Philosciinae [now the family Philosciidae], having some characters in common with each. In a choice between these two sub-families, Haloniscus probably would be better placed in the Philosciinae". Vandel (1973b: 101) considers the genus incertae sedis while Taiti et al. (1995) include it in the family Scyphacidae as presently defined, close to the genus Alloniscus Dana, 1854, but with the limitation that the family most probably is not monophyletic. The discovery of three new species of Haloniscus does not add further information for the inclusion of the genus in a different family of Oniscidea, and for the time being we follow the most recent opinion of Taiti et al. (1995) and tentatively retain the genus in the family Scyphacidae s.l. Any new family placement for the genus Haloniscus can be reconsidered when a phylogenetic revision of the family Scyphacidae is undertaken.

With the addition of three new species and the exclusion of $H$. stepheni from the genus, Haloniscus presently includes five species all inhabiting athalassic waters: $H$. searlei, with a wide distribution in Australia where it occurs in salt lakes of Western Australia, South Australia, Victoria and Tasmania (Ellis and Williams, 1970); H. anophthalmus, from anchialine waters in a limestone cave in the Isle of Pines, New Caledonia (Taiti et al., 1995); $H$. tomentosus sp. nov., H. longiantennatus sp. nov. and $H$. stilifer sp. nov., from underground waters of Western Australia. All species are certainly secondarily adapted to live in waters (see Bayly and Williams, 1966; Bayly and Ellis, 1969; Blinn et al., 1989 for $H$. searlei; Taiti et al., 1995 for $H$. anophthalmus).

The presence of three new species in saline 
groundwater in a long emergent landmass in arid Australia (Humphreys, 1999), together with the occurrence of $H$. anophthalmus in anchialine habitats in New Caledonia suggests a considerable age for the genus and remarkable morphological conservation. According to Kroenke (1996) the separation of New Caledonia from the Australian plate began in the Late Cretaceous, about $74 \mathrm{Ma}$ ago.

\section{Key to species of Haloniscus}

1. Eyes present; antennule with several superimposed aesthetascs at apex; pereopods 1-4 subchelate; male pereopod 1 merus wider than long; male pereopods $2-7$ ischium with a brush of long setae on sternal margin

Haloniscus searlei

Eyes absent; antennule with 1 or 2 aesthetascs at apex; pereopods not subchelate; male pereopod 1 merus longer than wide; male pereopods 2-7 ischium with no long setae on sternal margin ... 2

2. Cephalon with no supra-antennal line; pleopod 1 exopod without marginal fringe of setae ..... Haloniscus anophthalmus

Cephalon with distinct supra-antennal line; pleopod 1 exopod with a marginal fringe of fine setae ... 3

3. Antennae very long, reaching posterior margin of pereonite 6; anterior pereopods without brush of scales on merus sternal margin; male pleopod 1 endopod with stout apical part .....

Haloniscus longiantennatus

Antennae shorter, reaching posterior margin of pereonite 2 or 3; anterior pereopods with a brush of scales on merus sternal margin; male pleopod 1 endopod with styliform apical part

... 4

4. Antennule with third article much shorter than second; exopods of male pleopods cordiform Haloniscus tomentosus

Antennule with third article as long as second; exopods of male pleopods ovoid

Haloniscus stilifer

Haloniscus tomentosus sp. nov.

Figures 2, 3

\section{Material Examined}

\section{Holotype}

б, (WAM C25006) Australia, Western Australia, Murchison Region, abandoned Cue water supply bores (BES 7039), 27⒗182'S, 117 59.382'E, 12 May 1999, W.F. Humphreys and H.J. Hahn.

\section{Diagnosis}

A blind species of Haloniscus characterized by a dorsum equipped with numerous scale-spines, antennule with third article much shorter than first and second, antenna with short apical organ, about $1 / 6$ the length of the third flagellar article, male pleopod 1 endopod with styliform apical part bent outwards, and cordiform exopods of male pleopods.

\section{Description}

Dimensions: $5.5 \times 1.6 \mathrm{~mm}$. Body colourless, elongate, about four times as long as wide, with pereon slightly broader than pleon (Figure 2A). Dorsum rough, hairy, due to the presence of numerous scale-spines of complex shape in the middle (Figure 2B), and digitate on the posterior margins (Figure 2C) of segments. Cephalon (Figures 2D-F) with vertex slightly excavated in middle frontal part; supra-antennal line present, slightly sinuous. Eyes absent. Pereonites 1-3 with straight posterior margins and right-angled posterior corners; pereonites 4-7 with posterior corners progressively more acute. Pleonites $2-5$ with very small posterior points (Figures 2A,G). Telson (Figure 2H) about twice as wide as long, with slightly concave sides and broadly rounded apex. Antennule (Figure 2I) with third article very short, much shorter than first and second, and bearing 1 (2?) aesthetasc near apex. Antenna (Figure 2J) short, reaching posterior margin of pereonite 2 ; fifth article of peduncle slightly curved, as long as flagellum; flagellum of three articles, the first longer than each of the others, second and third articles bearing 2 and 3 aesthetascs respectively, apical organ short and thickset, about $1 / 6$ the length of the third flagellar article. Mandibles (Figures 2K,L) with molar penicil consisting of 5 or 6 plumose setae, $2+1$ free penicils in the right and $1+1$ in the left mandible. Maxillule (Figure 2M) outer branch with a small additional tooth at the base of the outer group of 4 large teeth. Maxilliped as in Figure 3A. Pereopods 1,2 - and to a lesser extent - 3 merus with a brush of scales on sternal margin (Figure $3 C)$; carpus and merus of all pereopods with some strong setae with digitate apex on sternal margin, larger on anterior pereopods; pereopod 1 carpus with cleaning device reduced to a few scales on distal margin, propodus distinctly curved, with two strong setae on distal part of sternal margin; pereopod 7 (Figure 3D) ischium with sternal margin straight. Genital papilla (Figure 3E) with ventral shield about three times as long as wide, and a slightly bilobed apex. Pleopods (Figures 3F-J) with all exopods fringed with fine setae and some strong spines; pleopod 1 (Figure 3F) exopod with convex outer margin and broadly rounded apex, endopod much longer than exopod with long and thin apical part bent outwards; pleopod 2 (Figure 3G) exopod 

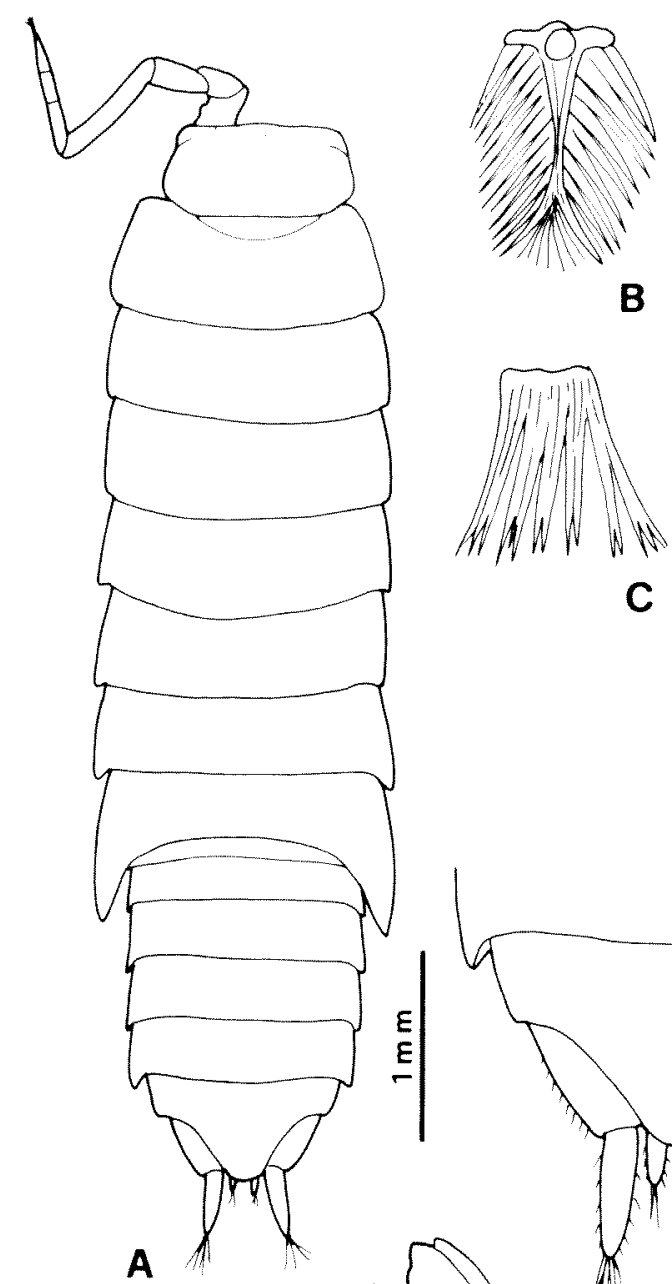

B

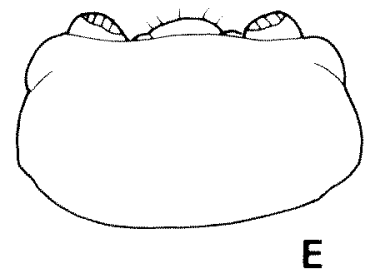

E

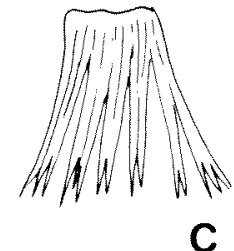

C
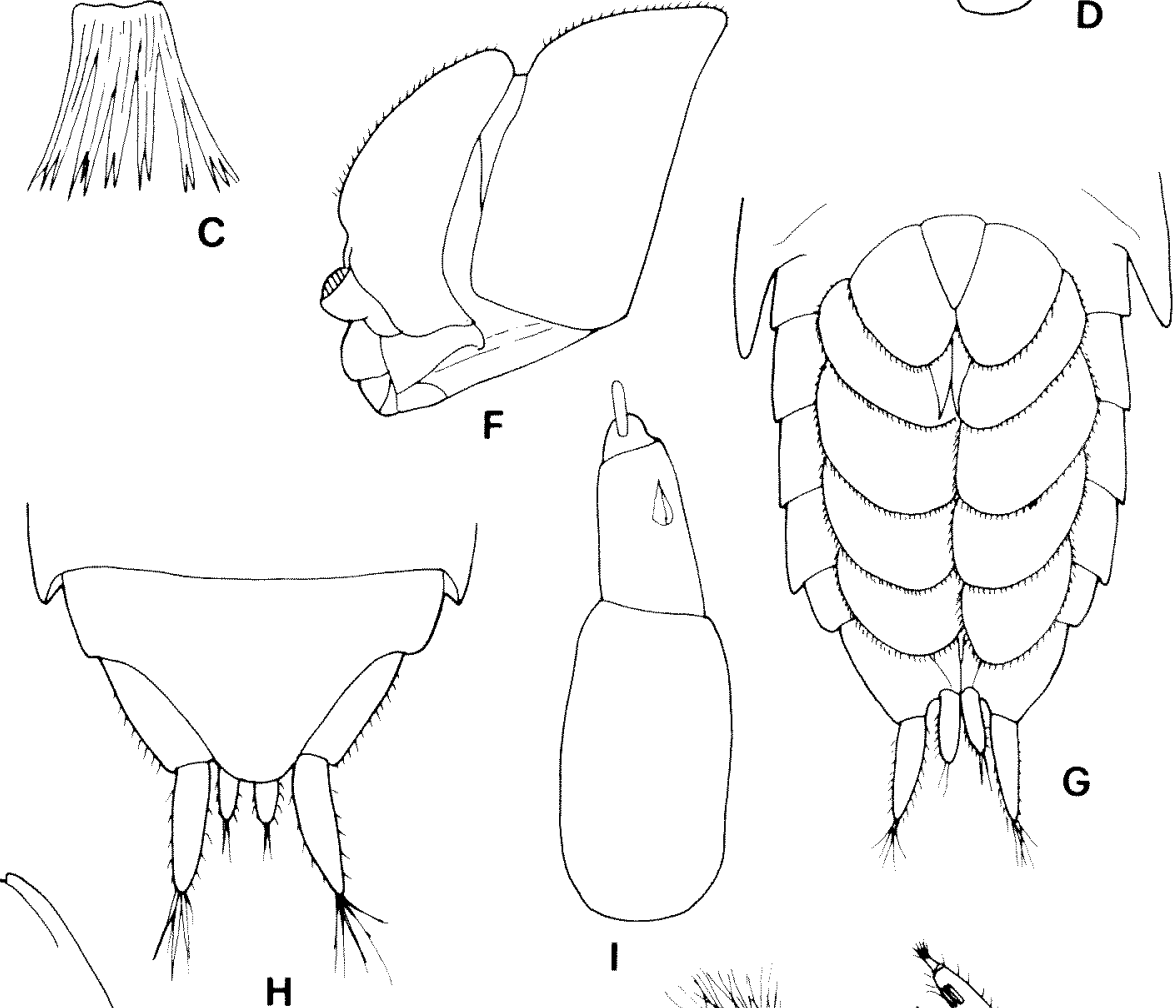

I
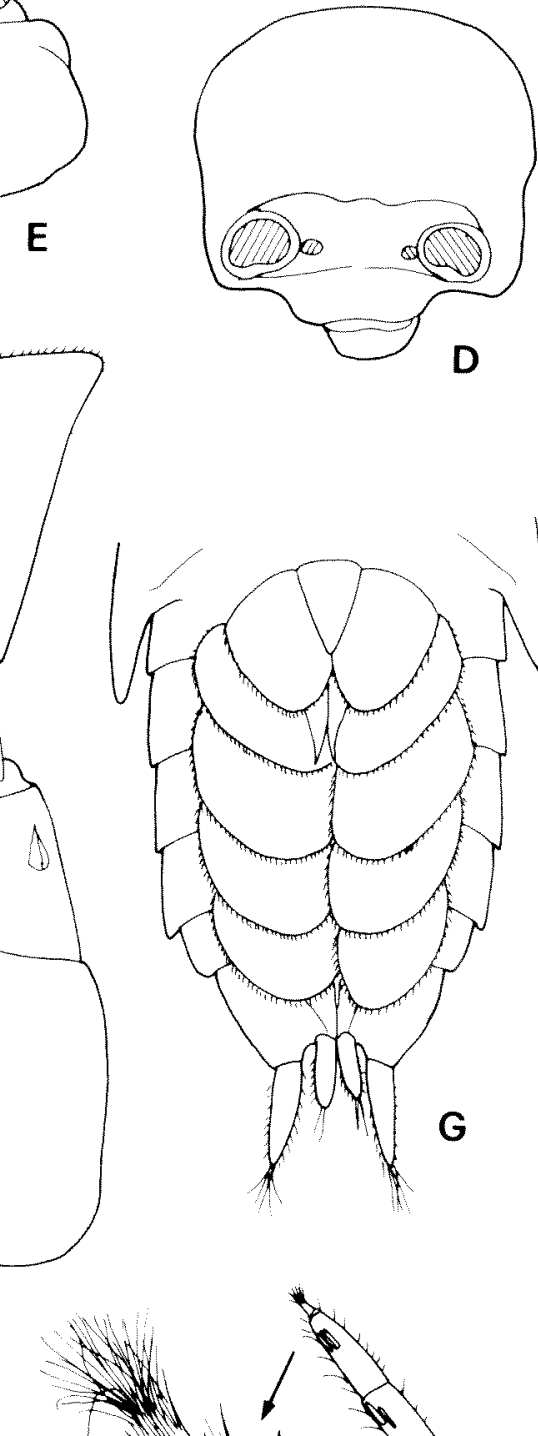

D
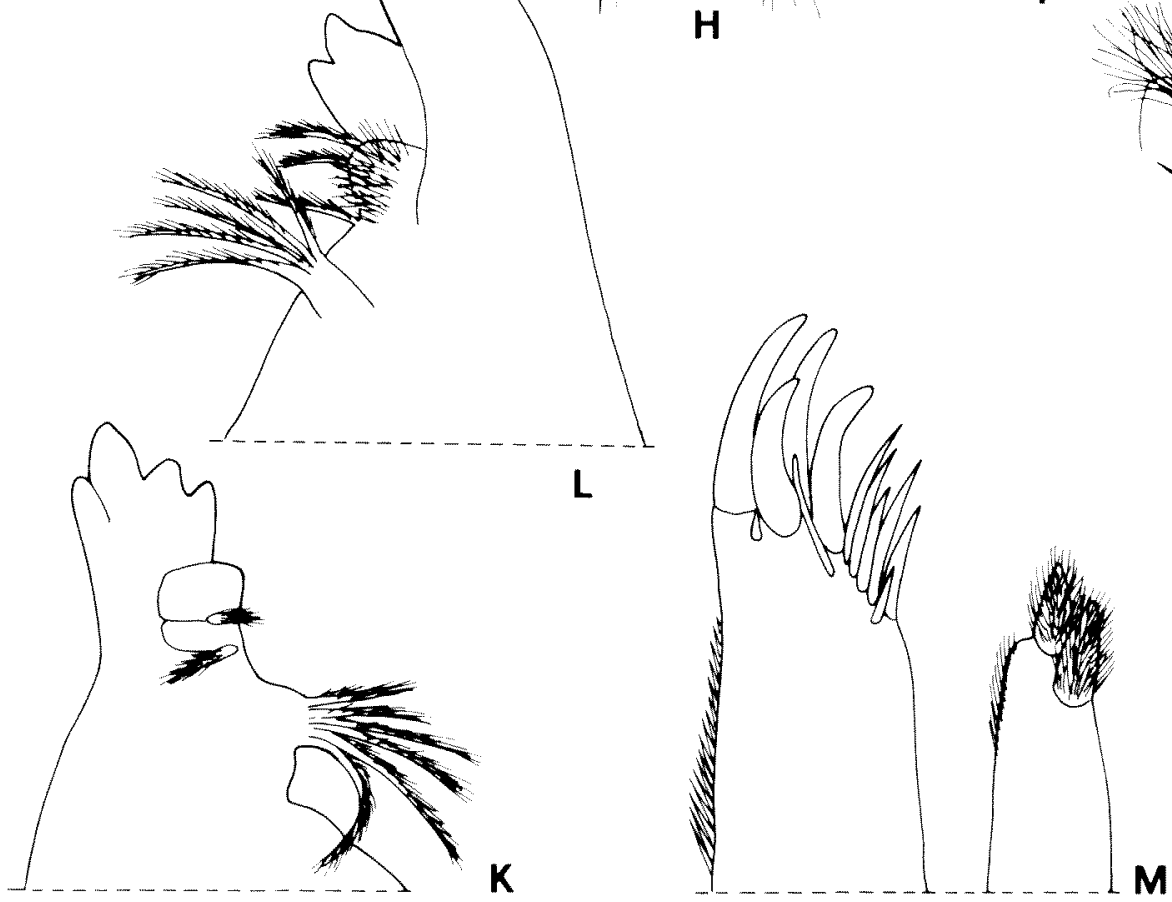

M

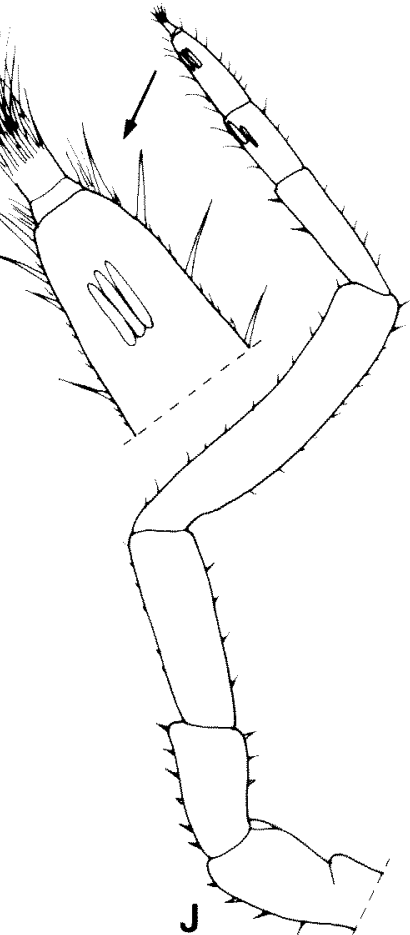

Figure 2 Haloniscus tomentosus sp. nov., holotype $\delta$ : A, whole specimen, dorsal view; B, dorsal scale-spine; C, scalespine on posterior margins of pereonites; D, cephalon, frontal view; $E$, cephalon, dorsal view; $F$, cephalon and pereonite 1, lateral view; $G$, pleon, ventral view; $H$, telson and uropods, dorsal view; 1 , antennule; J, antenna; $K$, right mandible; $L$, left mandible; $M$, maxillule. 

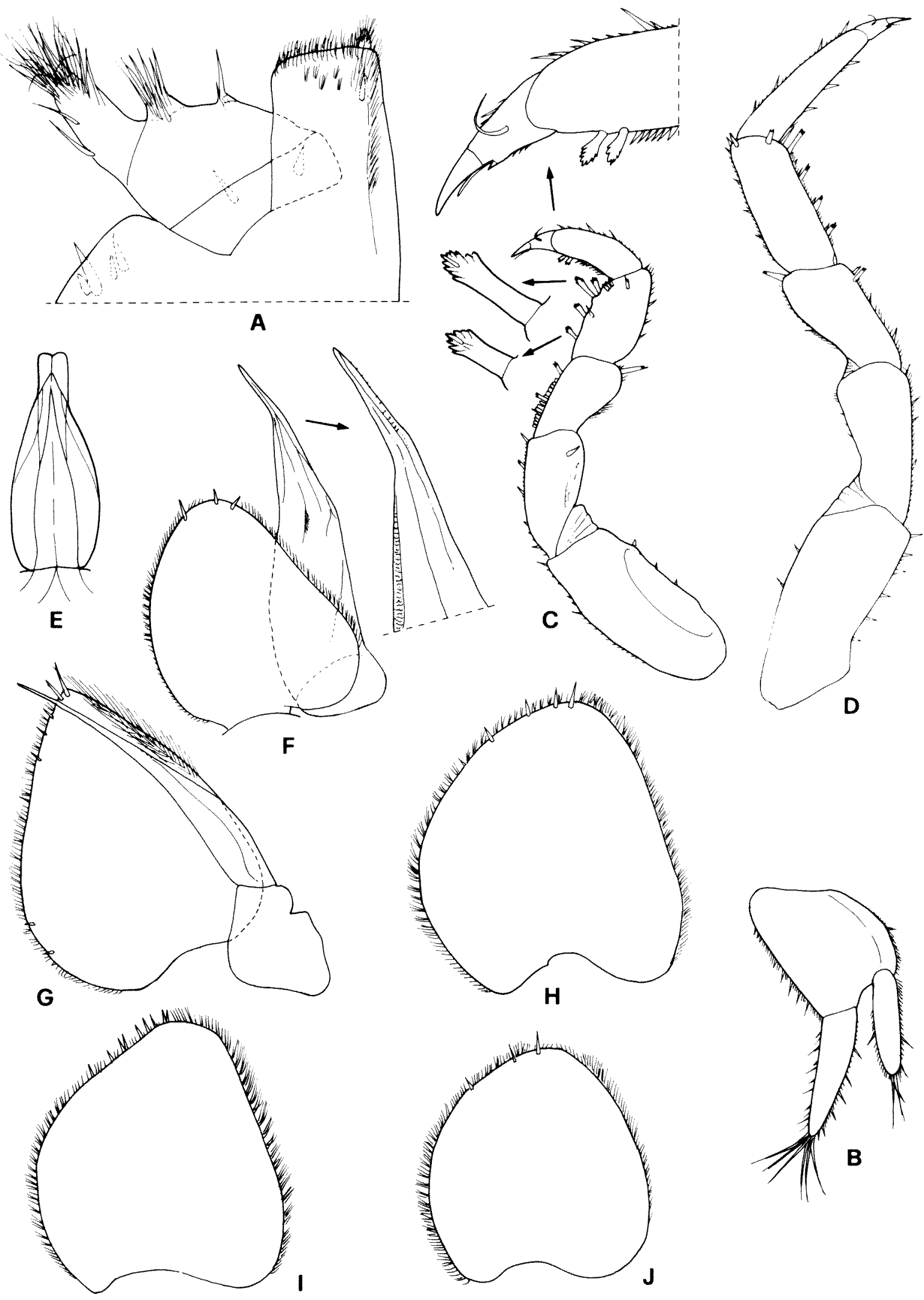

Figure 3 Haloniscus tomentosus sp. nov., holotype $\delta$ : A, maxilliped; B, uropod; C, pereopod 1; D, pereopod 7; E, genital papilla; F, pleopod $1 ; \mathrm{G}$, pleopod $2 ; \mathrm{H}$, pleopod 3 exopod; I, pleopod 4 exopod; J, pleopod 5 exopod. 
cordiform with subacute apex, endopod slightly longer than exopod; pleopods 3-5 exopods (Figures $3 \mathrm{H}-\mathrm{J}$ ) cordiform with broadly rounded apex. Uropod (Figures 2H, 3B) with protopod slightly shorter than telson apex; endopod inserted proximally to exopod.

\section{Remarks}

Haloniscus tomentosus is readily distinguished from $H$. searlei by the lack of eyes and shape of male pereopods and pleopods (cf. redescription of the latter species by Williams, 1970). For the lack of eyes and colourless body the new species resembles $H$. anophthalmus, $H$. longiantennatus sp. nov. and $H$. stilifer sp. nov. It differs from all these species in having a tomentose dorsum, antennule with third article very short, antenna with short apical organ and cordiform male pleopod 2 exopod; from $H$. anophthalmus also in the presence of a distinct supra-antennal line and shape of the male pleopod 1 [cf. figures 3c,d in Taiti et al. (1995)].

\section{Etymology}

Latin: tomentosus $=$ tomentose, hairy. The name refers to the hairy appearance of the dorsal body surface due to the presence of numerous scale-spines.

\section{Haloniscus longiantennatus sp. nov. Figures 4, 5}

\section{Material Examined}

\section{Holotype}

o, (WAM C25007), Australia, Western Australia, Murchison Region, Lake Way, site 264 (BES 7203), sample $5 \mathrm{~b}(0-8 \mathrm{~m}), 26^{\circ} 41.238^{\prime} \mathrm{S}, 120^{\circ} 18.156^{\prime} \mathrm{E}, 21$ May 1999, W.F. Humphreys and H.J. Hahn.

\section{Paratypes}

Australia: Western Australia, Murchison Region: 1 \&, (WAM C25008), Lake Way, site 284 (BES 7190),

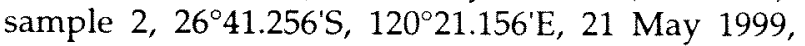
W.F. Humphreys and H.J. Hahn; $3 \delta \delta, 4$ specimens in poor condition, (WAM C25009), Lake Way, site

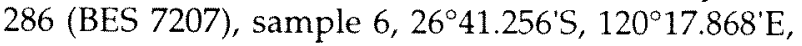
21 May 1999, W.F. Humphreys and H.J. Hahn; $1 \delta^{\circ}$, same data (MZUF8000).

\section{Diagnosis}

A blind species of Haloniscus with elongated appendages, particularly the antennae which reach the posterior margin of pereonite 6 , ovoid exopods of male pleopods, and male pleopod 1 endopod with stout apical part.

\section{Description}

Maximum dimensions: $\delta, 6 \times 1.8 \mathrm{~mm} ; \%, 6.5 \times 1.8$ $\mathrm{mm}$. Body colourless, elongate, about four times as long as wide, with pereon slightly broader than pleon (Figure 4A). Dorsum smooth with numerous long triangular scale-spines (Figure 4B). Cephalon (Figures $4 \mathrm{C}-\mathrm{E}$ ) with supra-antennal line curved at sides and straight in the middle part. Eyes absent. Pereonites 1-4 with straight posterior margins and right-angled posterior corners; pereonites 5-7 with posterior corners progressively more acute. Pleonites 3-5 with very small posterior points (Figures 4A,F). Telson (Figure 4F) about twice as wide as long, with slightly concave sides and truncate apex. Antennule (Figure 4G) with first article the longest, second and third subequal in length, 2 aesthetascs at apex. Antenna (Figure 4H) very long, reaching posterior margin of pereonite 6 ; fifth article of peduncle shorter than flagellum; flagellum of three articles, the first the longest and the second the shortest, second and third articles each bearing 2 aesthetascs; apical organ longer than in the preceding species. Buccal pieces (Figures 4I$\mathrm{K}, 5 \mathrm{~A}$ ) as in H. tomentosus. Pereopods (Figures 5B,C) elongated, especially carpus and dactylus. Pleopods with all exopods bearing a fringe of fine setae and some strong spines. Uropod (Figure 4F) with protopod flattened and not grooved on outer margin, longer than telson apex; endopod inserted slightly proximally to exopod, both exopod and endopod elongated, exopod about twice as long as protopod, endopod 2/3 as long as exopod.

Male: Pereopod 1 (Figure 5B) carpus with some strong setae with digitate apex on sternal margin, with cleaning device consisting of a large setose area; propodus slightly curved, with one strong seta on distal part of sternal margin. Pereopod 7 (Figure $5 C$ ) ischium with sternal margin slightly convex. Genital papilla as in Figure 5D. Pleopod 1 (Figure 5E) exopod ovoid, almost as long as endopod; endopod with thickset apical part. Pleopod 2 (Figure 5F) exopod ovoid, endopod distinctly shorter than exopod. Pleopods $3-5$ exopods as in Figures 5G-I.

\section{Remarks}

The new species is morphologically close to the other blind species of the genus, and is distinguished by the long appendages, especially antennae and uropods. It also differs from $H$. tomentosus in having triangular instead of complex shaped dorsal scale-spines, longer apical article of the antennule, male exopods of pleopods ovoid instead of cordiform; from $H$. tomentosus and $H$. stilifer also in the stout distal part of the male pleopod 1 endopod. In this character $H$. longiantennatus resembles $H$. anophthalmus, which however shows a more complex apex of that appendage and the male pleopod 1 exopod cordiform, instead of ovoid, not fringed with setae [cf. figures 3c, d in Taiti et al. (1995)].

Haloniscus stilifer has been collected in the same 

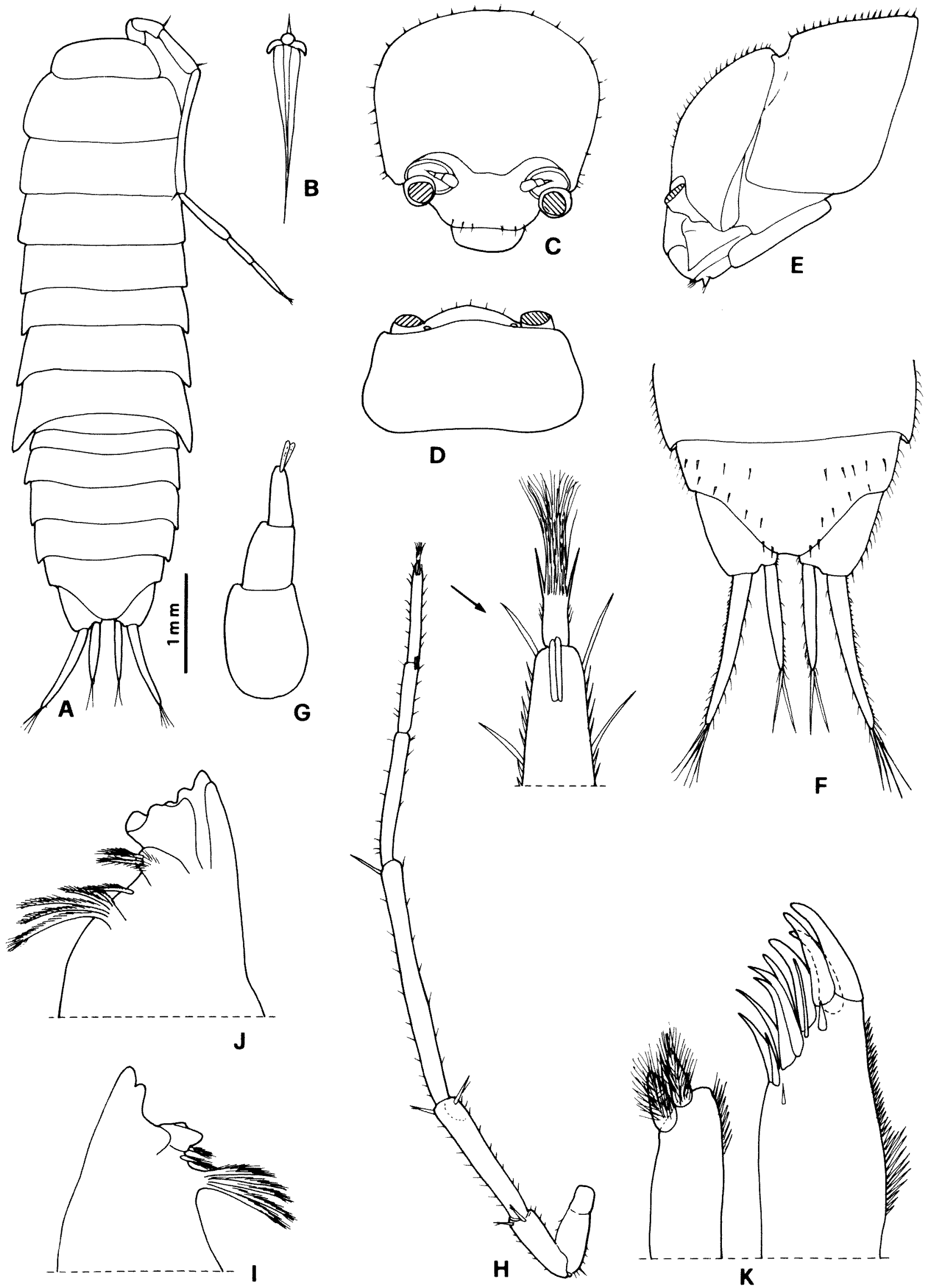

D
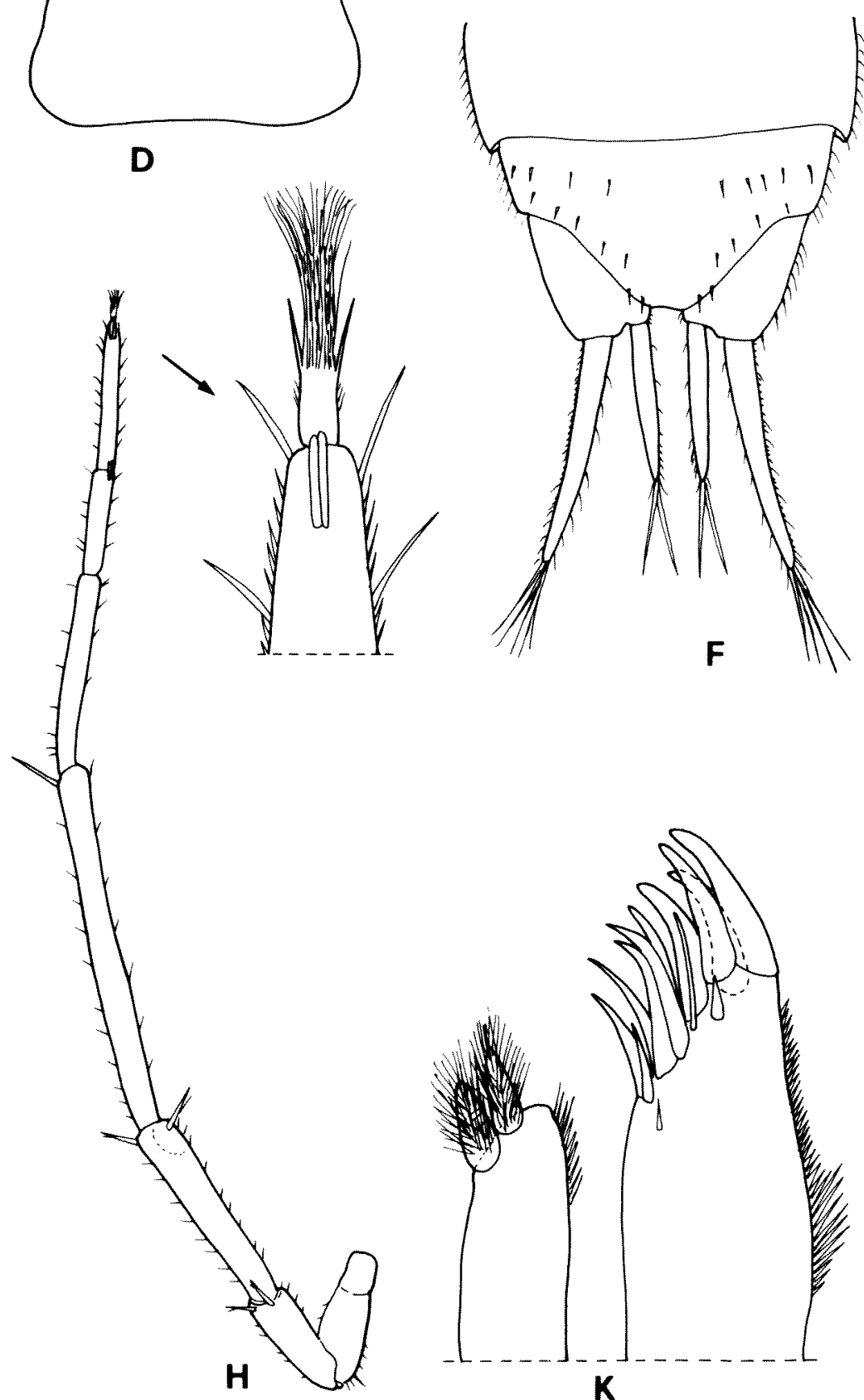

Figure 4 Haloniscus longiantennatus sp. nov., $\delta$ : A, holotype, dorsal view; $B$, dorsal scale-spine; $C$, cephalon, frontal view; $\mathrm{D}$, cephalon, dorsal view; $\mathrm{E}$, cephalon and pereonite 1, lateral view; F, pleonite 5 , telson and uropods, dorsal view; $G$, antennule; $H$, antenna; I, right mandible; J, left mandible; $K$, maxillule. 


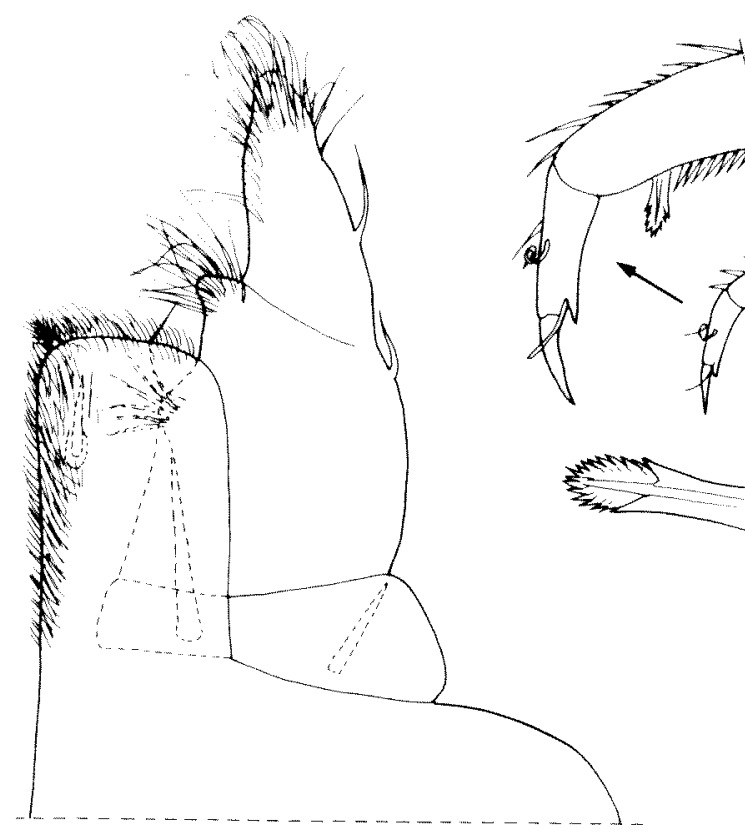

A
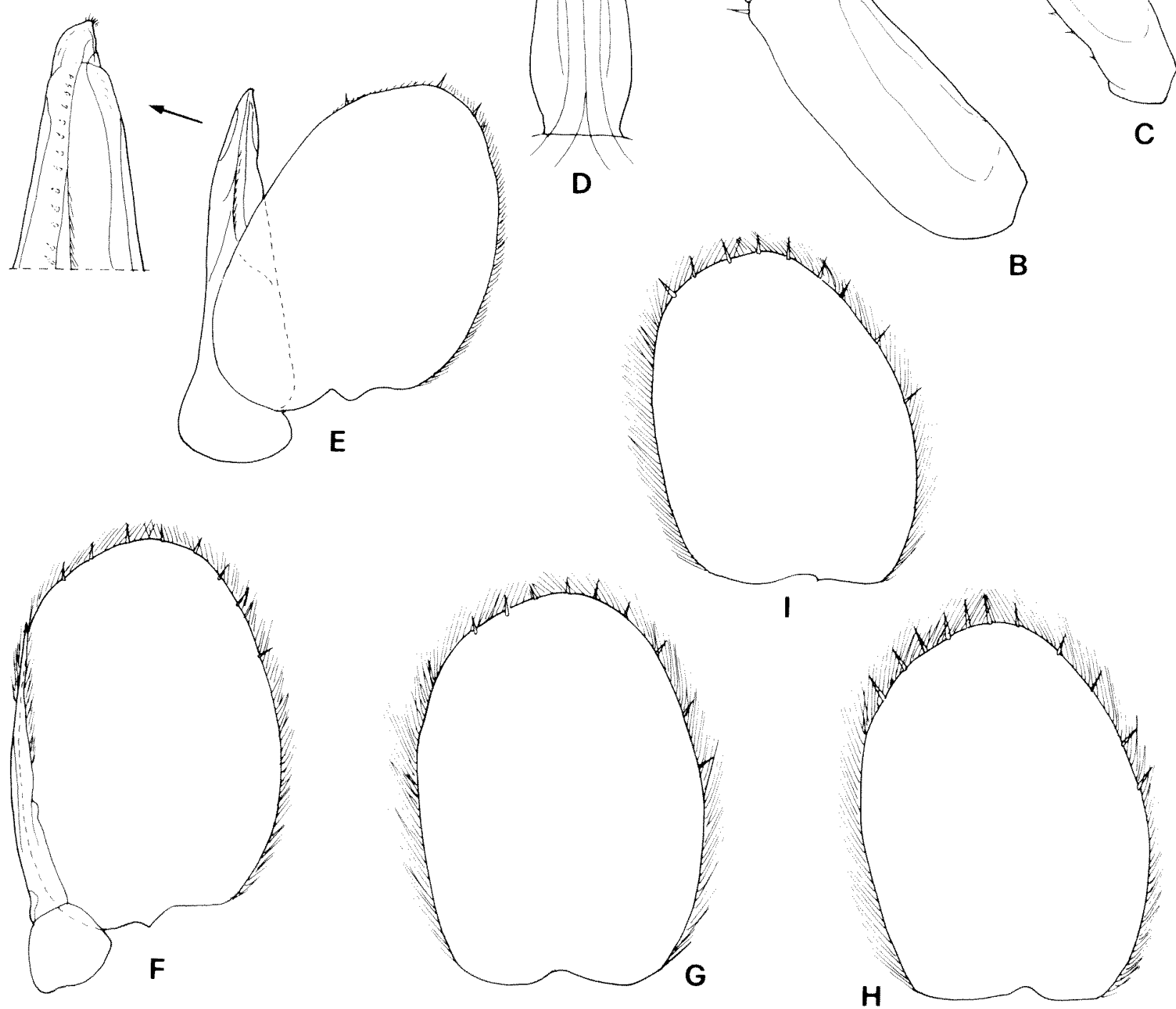

Figure 5 Haloniscus longiantennatus sp. nov., $\delta$ : A, maxilliped; B, pereopod 1; C, pereopod 7; D, genital papilla; E, pleopod 1; F, pleopod 2; $\mathrm{G}$, pleopod 3 exopod; $\mathrm{H}$, pleopod 4 exopod; I, pleopod 5 exopod. 
calcrete system as $H$. longiantennatus. The presence of two species of a single genus of Oniscidea in the same groundwaters is not surprising, as multiple sympatric congeners of stygobites are increasingly being found to inhabit aquifers in the palaeodrainage systems of the Western Shield of Australia and adjacent karst areas. For example, 10 species of Nedsia (Amphipoda: Melitidae) (Bradbury and Williams, 1996; J.H. Bradbury, personal communication, 2000) and 14 species of Chydeakata (Amphipoda: Paramelitidae) (Bradbury, 2000) have been described from individual karst areas in northwestern Australia. In addition, numerous examples of sympatric genera of stygal dytiscids occur in some of the calcrete aquifers (Watts and Humphreys, 1999, 2000, unpublished), including some aquifers containing Haloniscus.

The regional, geomorphological and hydrogeological setting of these calcrete aquifers, and hypotheses about their origin, are discussed elsewhere (Watts and Humphreys, 2000; Humphreys, 1999, 2001). Molecular evidence supports a late Tertiary invasion of the groundwater by the Dytiscidae (S. Hinze and S. Cooper, personal communication, 2000) with the onset of regional aridity. However, the invasion of the groundwater by some of the crustaceans is likely to have been much earlier but molecular evidence has yet to be obtained; this is an area of active research.

\section{Etymology}

Latin: longus = long + antennatus = bearing antennae. The name refers to the long antennae which reach the posterior margin of pereonite 6 .

\section{Haloniscus stilifer sp. nov.}

Figures 6,7

\section{Material Examined}

\section{Holotype}

q, (WAM C25010), Australia, Western Australia, Murchison Region, Lake Way, site 264 (BES 7201), sample 5A (0-2 m), 26 ${ }^{\circ} 41.238^{\prime} \mathrm{S}$, $120^{\circ} 18.156^{\prime} \mathrm{E}, 21$ May 1999, W.F. Humphreys and H.J. Hahn.

\section{Paratype}

Australia: Western Australia, Murchison Region: 10 , (WAM C25011), Lake Way, saline mineral exploration bore (BES 7165), sample 5, 26 $41.238^{\prime} \mathrm{S}$, $120^{\circ} 18.156^{\prime} \mathrm{E}, 19$ May 1999 , W.F. Humphreys and H.J. Hahn.

\section{Diagnosis}

A blind species of Haloniscus characterized by a brush of scales on sternal margin of pereopods 1-3 merus and carpus, styliform distal part of male pleopod 1 endopod, and all male pleopods with ovoid exopods.

\section{Description}

Dimensions: $\delta, 5 \times 1.5 \mathrm{~mm}$;, $5.5 \times 1.5 \mathrm{~mm}$. Body colourless, elongate, about four times as long as wide, with pereon slightly broader than pleon (Figure 6A). Dorsum smooth, with some triangular scale-spines (Figure 6B). Cephalon (Figures 6C-E) with supra-antennal line sinuous. Eyes absent. Pereonites 1-4 with straight posterior margins and rounded posterior corners; pereonites 5-7 with posterior corners progressively more acute. Pleonites 3-5 with very small posterior points (Figures 6A, F). Telson (Figure 6F) about twice as wide as long, with slightly concave sides and rounded apex. Antennule (Figure 6G) with first article the longest, second and third subequal in length, 2 aesthetascs at apex. Antenna (Figure 6H) shorter than in the preceding species, reaching posterior margin of pereonite 3; fifth article of peduncle almost as long as flagellum; flagellum of three articles of similar length, second and third articles bearing 1(?) and 2 aesthetascs respectively, apical organ slightly longer than in $H$. longiantennatus. Mandibles (Figures 61,J) with molar penicil consisting of only 2 or 3 plumose setae. Maxillule (Figure 6K) and maxilliped (Figure 7A) as in $H$. tomentosus. Pereopods 1-3 carpus and merus with a brush of scales on sternal margin. Pleopods with all exopods bearing a fringe of fine setae and some strong spines. Uropod (Figure 6F) similar to that of $H$. longiantennatus, with endopod relatively shorter in comparison to exopod.

Male. - Pereopod 1 (Figure 7B) carpus with a line of strong trifid setae on sternal margin, with cleaning device consisting of a large setose area; propodus slightly curved, with 2 strong setae with serrate apex on distal part of sternal margin. Pereopod 7 (Figure 7 C) ischium with sternal margin straight without apparent setation. Genital papilla as in Figure 7D. Pleopod 1 (Figure 7E) exopod ovoid, much shorter than endopod; endopod with styliform apical part slightly bent outwards. Pleopod 2 (Figure 7F) exopod ovoid, endopod distinctly longer than exopod. Pleopods 3-5 exopods (Figures 7G-I) ovoid.

\section{Remarks}

In the ovoid shape of the exopods of the male pleopods Haloniscus stilifer is close to $H$. longiantennatus from which it differs in having shorter antennae, pereopods 1-3 carpus and merus with a brush of scales on sternal margin, styliform apical part of the male pleopod 1 endopod. It differs from $H$. tomentosus essentially in the shape of the dorsal scale-spines, the longer distal article of the antennule, and the ovoid, instead of 

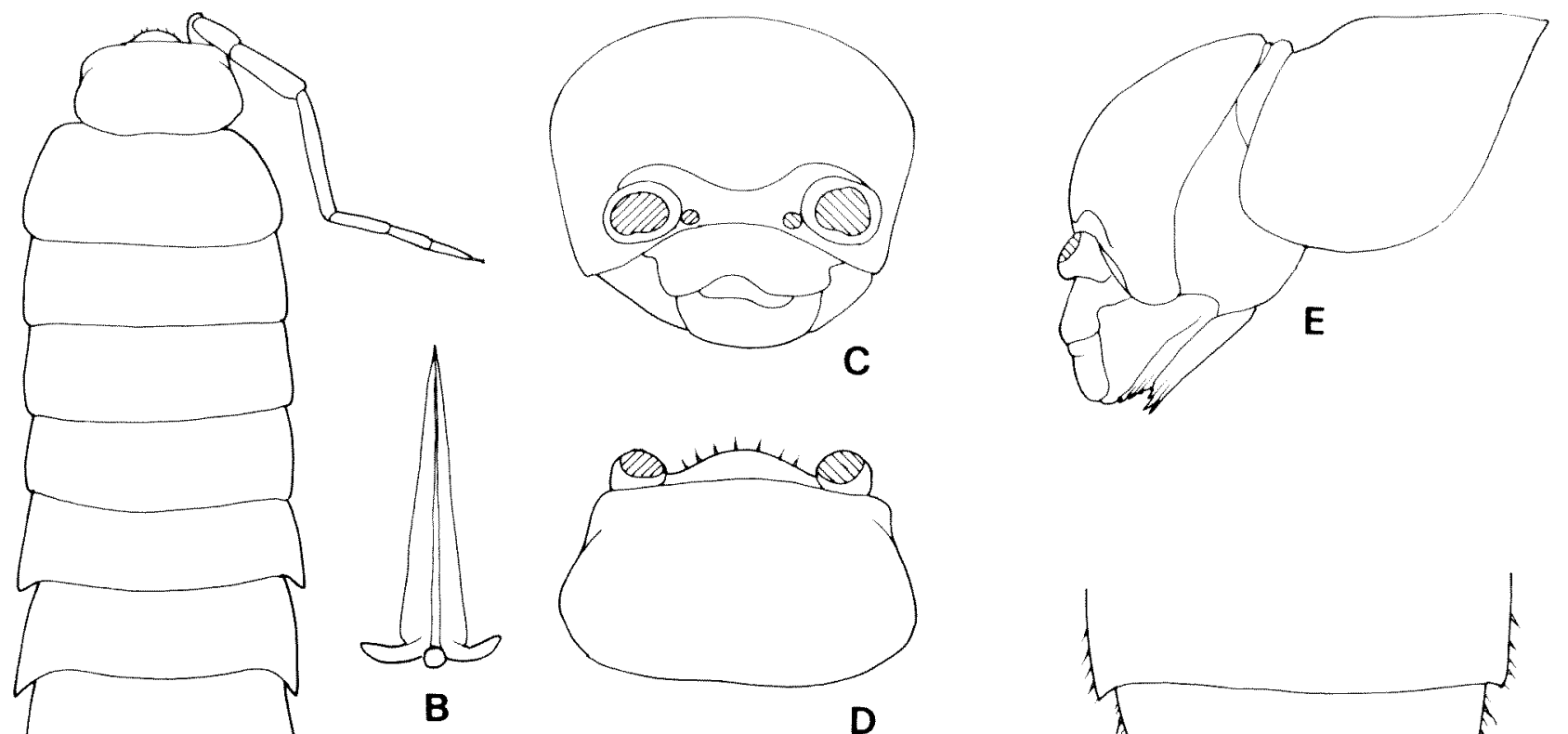

B
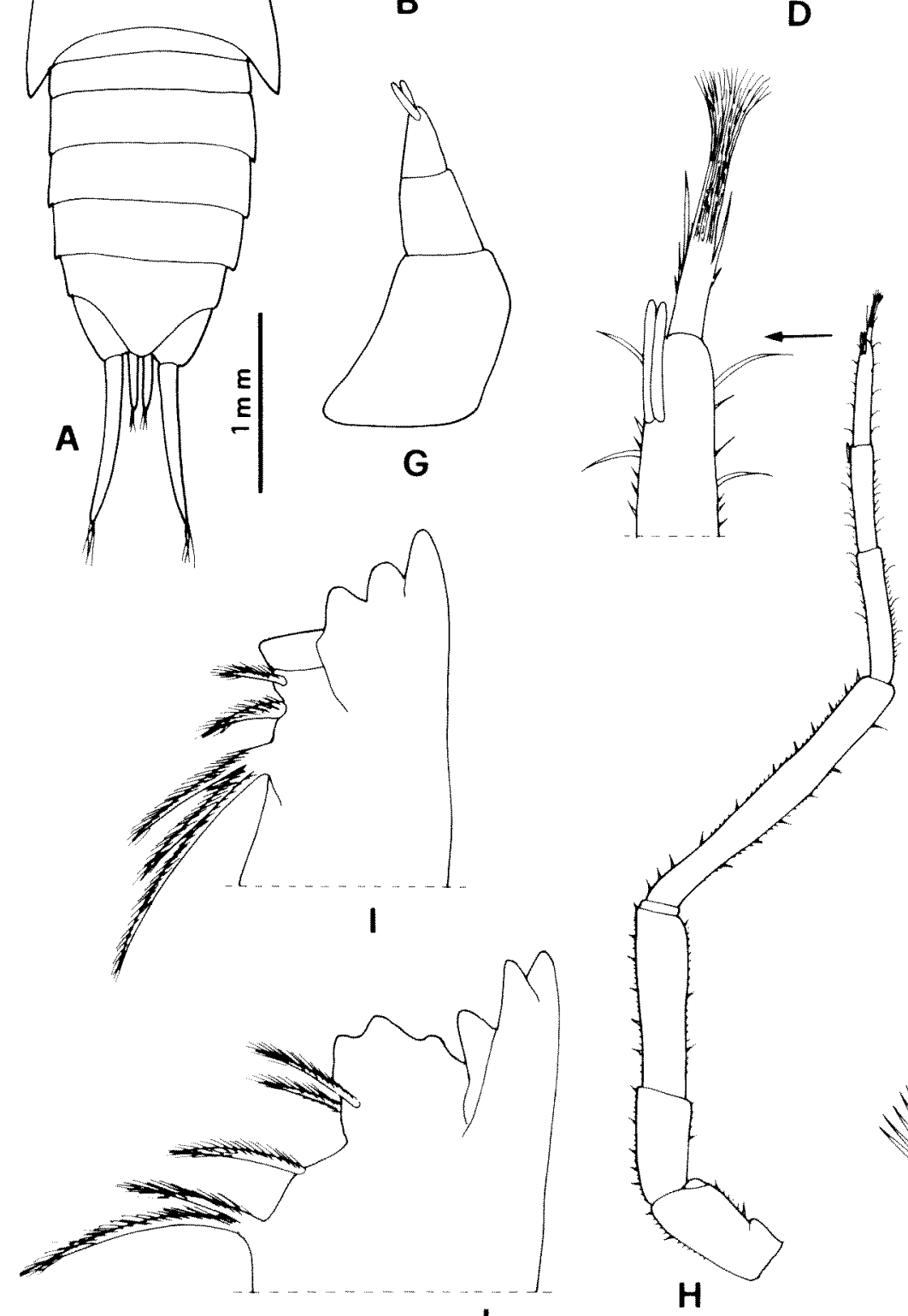

$\mathbf{J}$

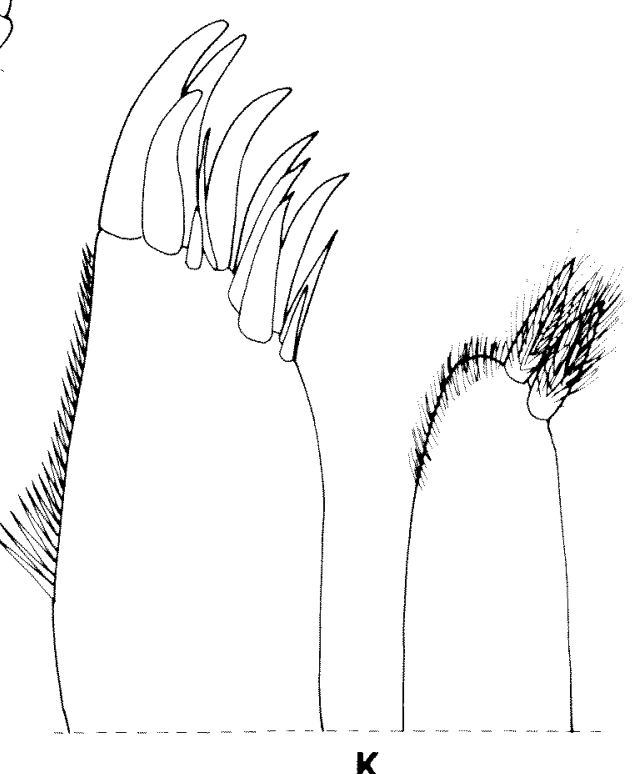

Figure 6 Haloniscus stilifer sp. nov, holotype $\$$ : A, whole specimen, dorsal view; B, dorsal scale-spine; C, cephalon, frontal view; $\mathrm{D}$, cephalon, dorsal view; $\mathrm{E}$, cephalon and pereonite 1 , lateral view. Paratype $\delta: F$, pleonite 5 , telson and uropods, dorsal view; $G$, antennule; $H$, antenna; I, right mandible; J, left mandible; $K$, maxillule. 


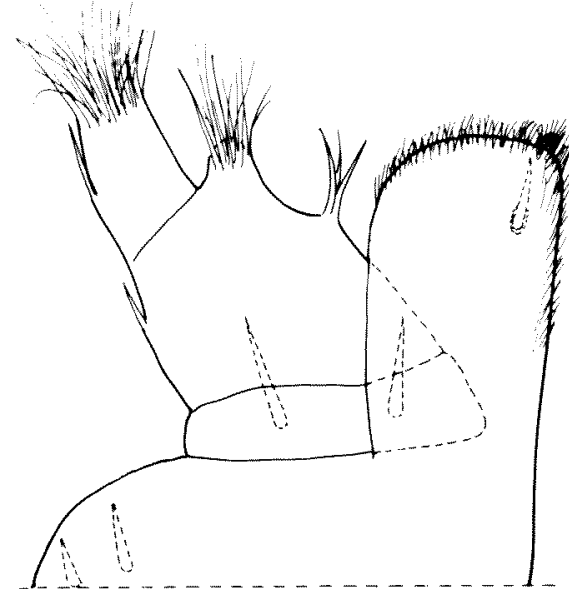

A
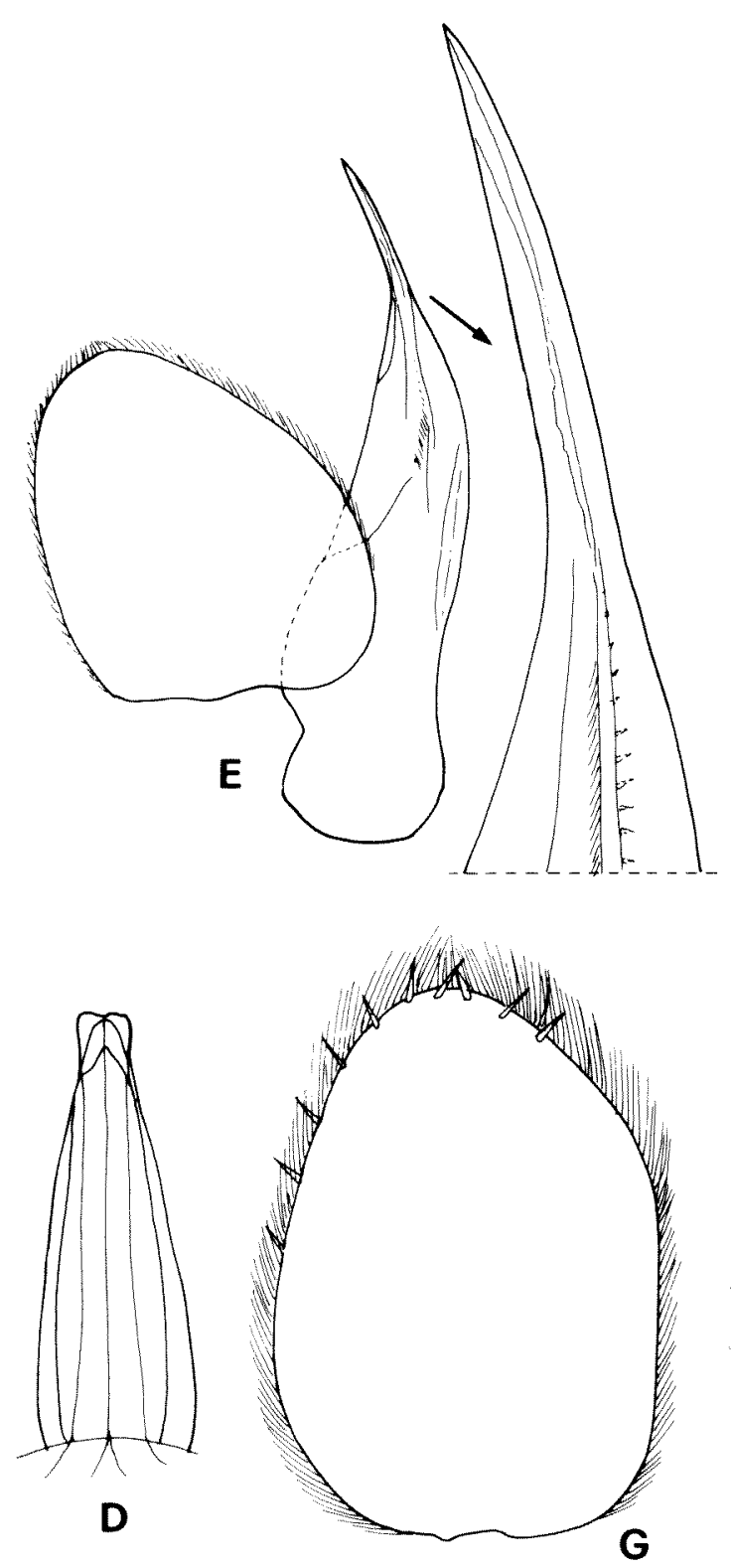

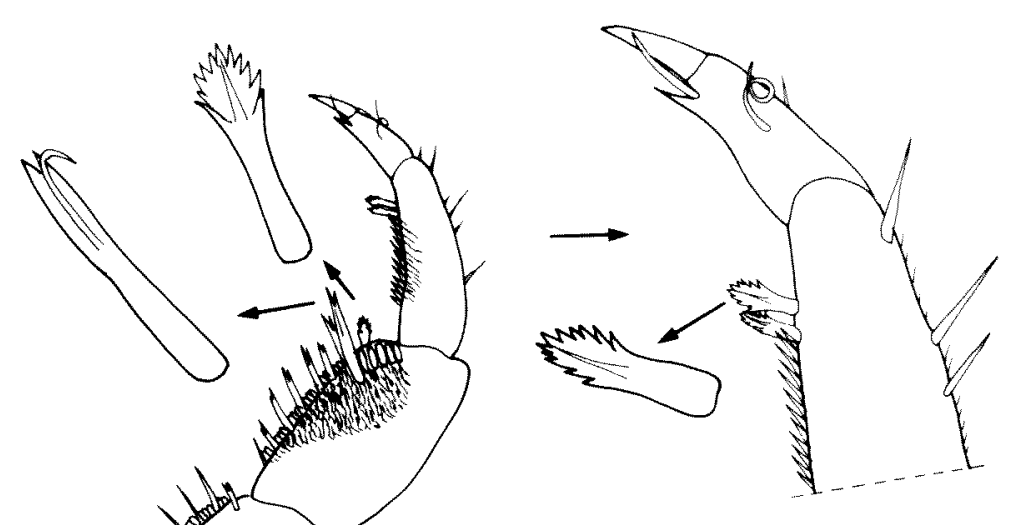

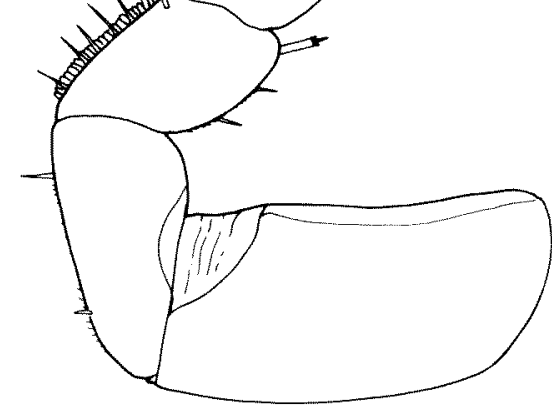

B
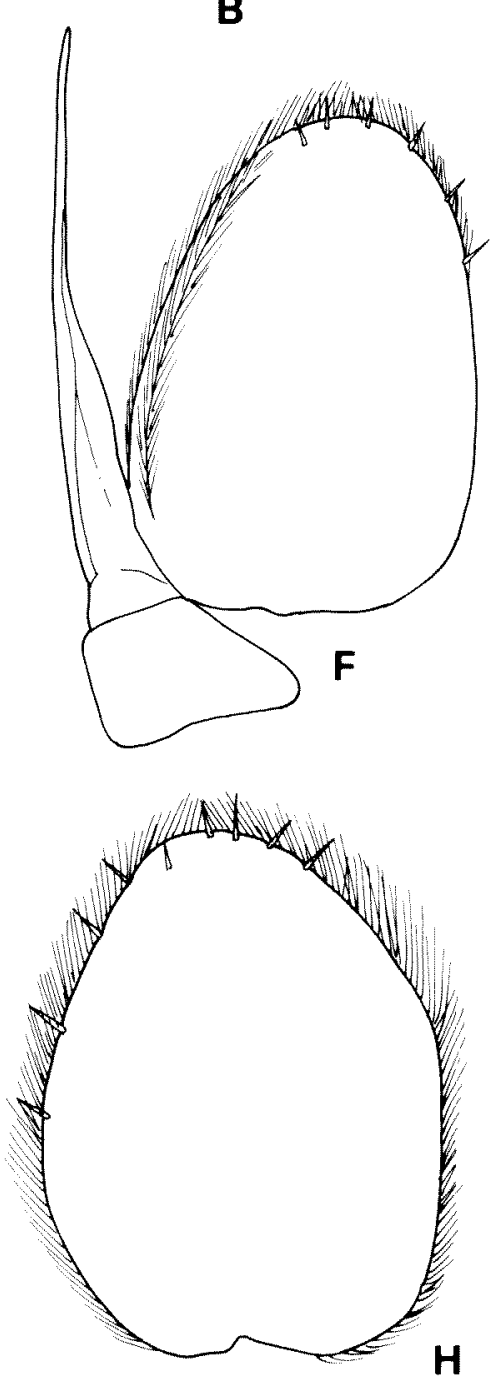

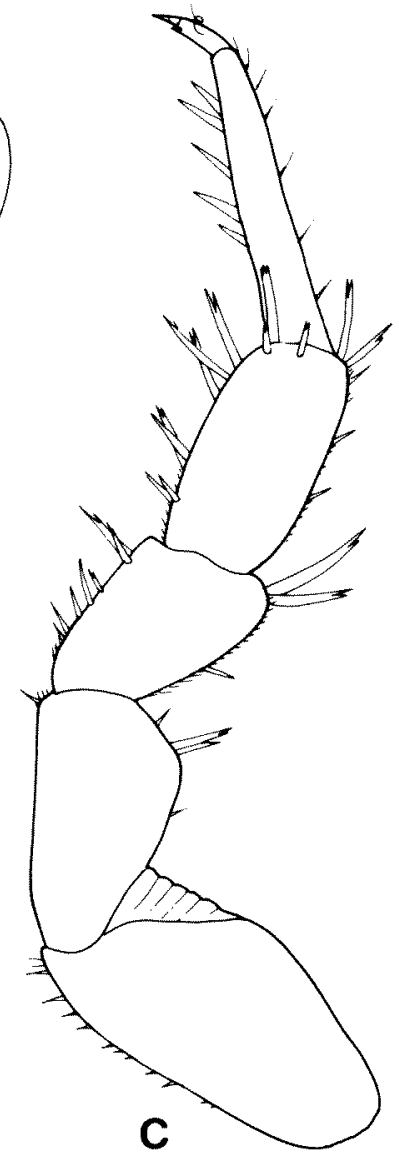

C

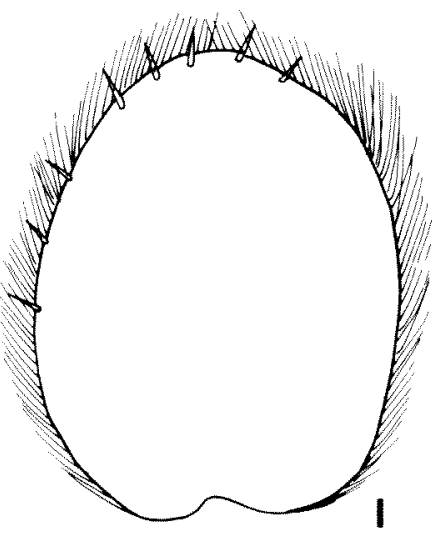

Figure 7 Haloniscus stilifer sp. nov., paratype $\delta$ : A, maxilliped; B, pereopod 1; C, pereopod 7; D, genital papilla; E, pleopod 1; F, pleopod 2; G, pleopod 3 exopod; $\mathrm{H}$, pleopod 4 exopod; I, pleopod 5 exopod. 
cordiform, exopods of the male pleopods. From $H$. anophthalmus it is readily distinguishable by the presence of supra-antennal line and the modifications of the male pereopods and pleopods.

\section{Etymology}

Latin: Stilus $=$ stylet + stem of ferre $=$ to bear. The name refers to the syliform apical part of the male pleopod 1 endopod.

\section{Family Philosciidae}

\section{Genus Andricophiloscia Vandel, 1973}

\section{Type Species}

Andricophiloscia melanesiensis Vandel, 1973 by original designation and monotypy.

\section{Diagnosis}

Body elongated with pleon narrower than pereon. Cephalon with supra-antennal line and no frontal line. Pereonites with one nodulus lateralis per side on each segment; noduli laterales inserted more or less at the same distance from the lateral margin; no gland pores and sulcus marginalis on pereonites. Pleon epimera reduced with very small posterior points. Antennule of three articles with some aesthetascs at apex. Antenna with flagellum of three articles. Molar penicil of mandible dichotomised, consisting of a tuft of plumose setae. Outer branch of maxillule with $4+6$ large teeth with simple apex; inner branch with two subequal penicils and no posterior point. Endite of maxilliped setose with a penicil on medial corner. Pereopods with flagelliform dactylar and ungual seta. Exopods of pleopods with no respiratory structures. Uropod with protopod and exopod grooved on outer margin; insertion of endopod slightly proximal to that of exopod.

\section{Remarks}

Re-examination of the syntypes and of new topotypic material of Haloniscus stepheni (see below) shows that this species does not belong to Haloniscus but to a genus of Philosciidae. In fact the species bears distinct noduli laterales on the pereonites, and the uropods have the protopod and exopod grooved on outer margin. Also the maxillipedal palp with no transverse suture distally to the middle tuft of setae, and the exopods of pleopods without a fringe of marginal fine setae are definitely of philosciid type.

Haloniscus stepheni shows all the characters of the genus Andricophiloscia erected for the species $A$. melanesiensis Vandel, 1973 from Japen Island, New Guinea. Vandel (1973a) established the new genus also on the basis of a peculiar character of the type species (the male pleopods extremely long, especially the endopod of pleopod 1 and 2). This condition is probably an autapomorphic character of this species and cannot be considered as a generic character; the same condition is found in other genera of philosciids, which include some species with very elongated male pleopods, e.g. the Palaearctic genus Chaetophiloscia Verhoeff, 1908 (C. hastata Verhoeff, 1929) and the Afrotropical genus Natalscia Verhoeff, 1942 (N. longistylata Ferrara and Taiti, 1985).

The generic diagnosis provided here is based on characters from Vandel's (1973a) description of the type species $A$. melanesiensis.

In the position of the noduli laterales on the pereonites (one line per side, all more or less at the same distance from the lateral margin), Andricophiloscia resembles the genus Littorophiloscia Hatch, 1947 (see Taiti and Ferrara, 1986) from which it differs in having the medial group of maxillular teeth with simple instead of bifid apex, and the ungual seta of the dactylus of pereopods flagelliform instead of apically enlarged. According to Vandel (1973b, 1977), other genera of Philosciidae from the Australian Region show a similar disposition of the noduli laterales, i.e. Australophiloscia Vandel, 1973, Huntonia Vandel, 1973, and Adeloscia Vandel, 1977. Unfortunately the descriptions of the number and position of the noduli laterales in these papers by Vandel are often inaccurate and sometimes wrong, so that comparisons are difficult without re-examination of the material. Taiti and Ferrara (1991) showed that Australophiloscia has a completely different disposition of the noduli laterales (d/c co-ordinates with a peak on pereonite 4 and two noduli per side on pereonite 7). Andricophiloscia differs from Huntonia and Adeloscia in having the molar penicil of the mandible dichotomised instead of simple.

The genus Andricophiloscia includes three species (one only tentatively): $A$. melanesiensis, A. stepheni and $A$. pedisetosa.

\section{Key to species of Andricophiloscia}

1. Endopod of male pleopod 1 very long, about eight times longer than exopod; endopod of male pleopod 2 flagelliform, more than twice as long as exopod

Andricophiloscia melanesiensis

Endopod of male pleopod 1 two to three times longer than exopod; endopod of male pleopod 2 slightly longer than exopod ......... 2

2. Eyes present; antennule with several aesthetascs at apex; male pereopods with no long setae on carpus; male pleopod 1 endopod with a short triangular distal part ... Andricophiloscia stepheni 

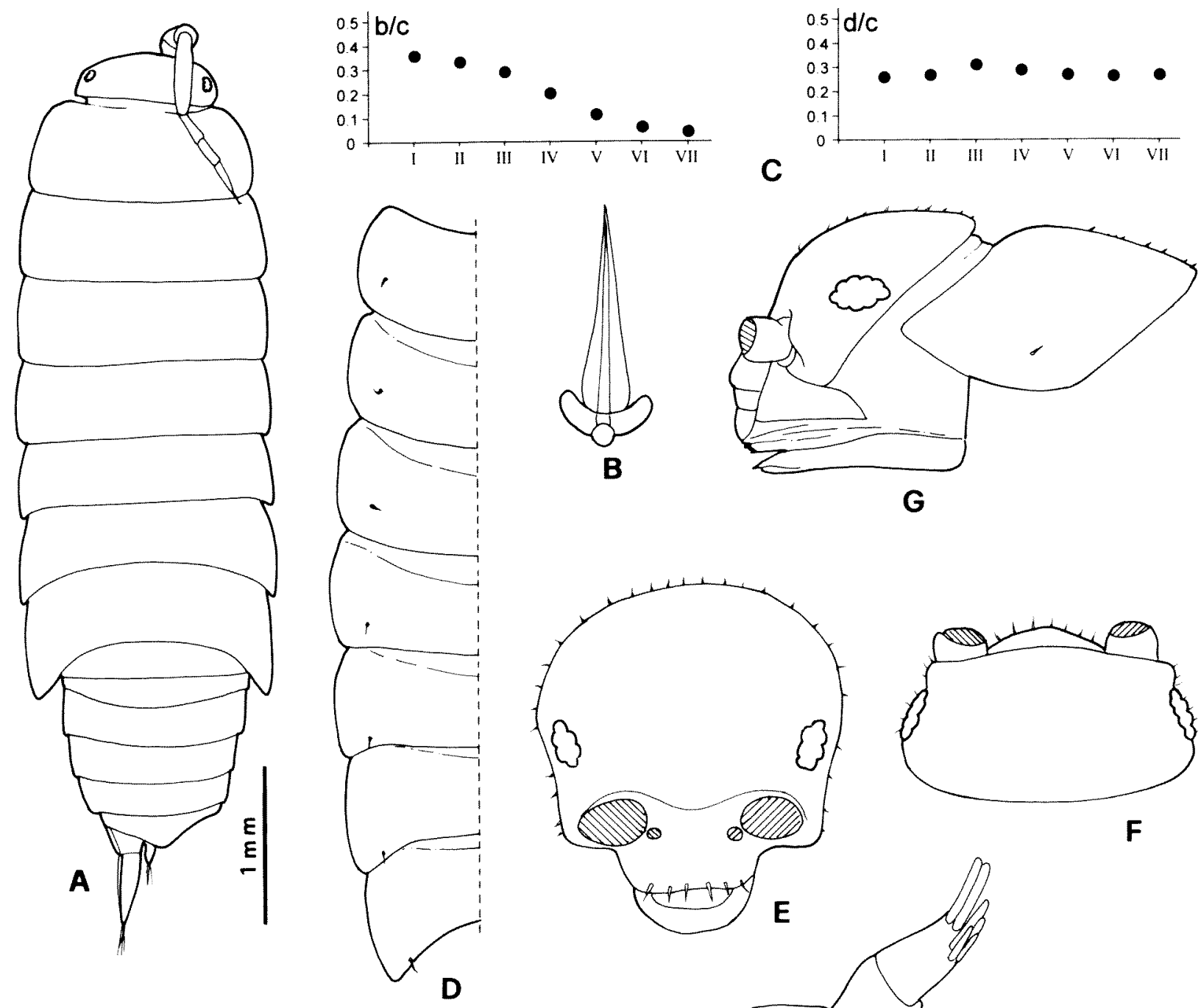

$\mathbf{F}$
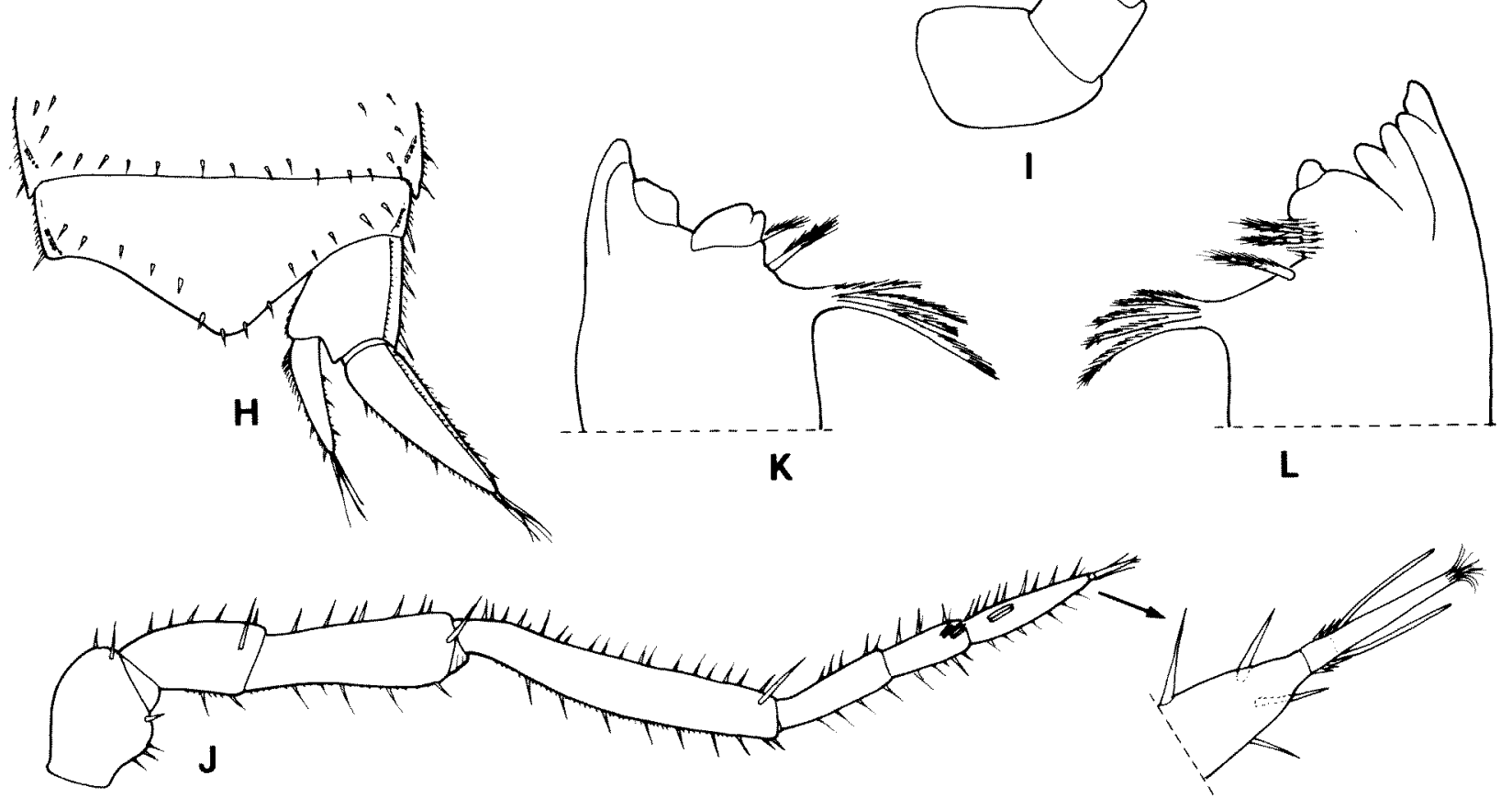

Figure 8 Andricophiloscia stepheni (Nicholls and Barnes, 1926), new specimens from Tenindewa, 8 : A, whole specimen, dorsal view; $\mathrm{B}$, dorsal scale-spine; $\mathrm{C}$, co-ordinates of the noduli laterales; $\mathrm{D}$, left side of pereonites showing position of noduli laterales; E, cephalon, frontal view; F, cephalon, dorsal view; $G$, cephalon and pereonite 1 , lateral view; $\mathrm{H}$, pleonite 5, telson and right uropod, dorsal view; I, antennule; J, antenna; K, right mandible; $\mathrm{L}$, left mandible. 
Blind; antennule with three petaliform aesthetascs at apex; male pereopods with many long setae on distal part of carpus; male pleopod 1 endopod with a long styliform distal part

Andricophiloscia pedisetosa

\section{Andricophiloscia stepheni \\ (Nicholls and Barnes, 1926), comb. nov. \\ Figures 8,9}

Haloniscus stepheni Nicholls and Barnes, 1926: 89, figures 1-6, plate $X$ figures 1-14; Vandel, 1973b: 101; Green, 1974: 245; Taiti et al., 1995: 321.

\section{Material examined}

\section{Syntypes}

Australia: Western Australia: $10 \delta \vec{\delta}, 8 q q$, (WAM C25012), Kokatea Creek, Tenindewa, under logs, 8 January 1926.

\section{Other Material}

Australia: Western Australia, Geraldton area: 2 o o, 10 q (WAM C25013), Kokatea Gully, Tenindewa (BES 7411), 28 37.543'S S, $115^{\circ} 21.751^{\prime} \mathrm{E}$, 9 August 1999, W.F. Humphreys; $1 \delta, 2 q$, same data (MZUF7573); 1 o, 1 j juv., 1 (WAM C25014), Kokatea Gully, Byrons Crossing (BES 7417), $28^{\circ} 34.412^{\prime} \mathrm{S}, 115^{\circ} 16.981^{\prime} \mathrm{E}, 9$ August 1999, W.F. Humphreys.

\section{Diagnosis}

A species of Andricophiloscia characterized by anterior pereopods with a brush of scales on merus and carpus, male pleopod 1 exopod cordiform and endopod with pointed apical part bent outwards.

\section{Redescription}

Maximum dimensions: $\delta, 5 \times 1.5 \mathrm{~mm} ; q, 5.5 \times 1.6$ mm (according to Nicholls and Barnes, 1926 the largest specimen is about $7 \mathrm{~mm}$ long, but all the syntypes re-examined do not reach $5 \mathrm{~mm}$ in length). Colour in alcohol pale brown, with darker pleon. Body (Figure 8A) moderately convex, elongated, more than three times as long as wide, with pleon distinctly narrower than pereon. Dorsum smooth with numerous triangular scale-spines (Figure 8B); noduli laterales (Figure 8D) distinct, with $\mathrm{b} / \mathrm{c}$ and $\mathrm{d} / \mathrm{c}$ co-ordinates as in Figure $8 \mathrm{C}$. A few gland pores are visible on posterior corners of pleonites 3-5, telson and along the marginal groove of uropodal protopod and exopod. Cephalon (Figures 8E-G) with small rounded lateral lobes; supra-antennal line slightly sinuous. Eyes small with about 10 ommatidia. Pereonites 1-3 with straight posterior margins and right-angled posterior corners; pereonites 4-7 with posterior corners progressively more acute. Pleonites $3-5$ with very small posterior points (Figure $8 \mathrm{~A}, \mathrm{H}$ ). Telson (Figure $8 \mathrm{H}$ ) more than twice as wide as long, distal part with slightly concave sides and rounded apex. Antennule (Figure 8I) with articles subequal in length, 2 aesthetascs at apex and a tuft of aesthetascs subapically. Antenna (Figure 8J) short, reaching middle of pereonite 2; fifth article of peduncle as long as flagellum; flagellum with first and third articles subequal in length, second shorter, second and third articles bearing ca. 5 and 2 aesthetascs respectively; apical organ about $2 / 5$ as long as third flagellar article, with two long setae at sides almost reaching apex and a small tuft of setae at apex. Mandibles (Figures $8 \mathrm{~K}, \mathrm{~L})$ with molar penicil consisting of 4 or 5 plumose setae, $2+1$ free penicils in the right and $1+1$ in the left mandible. Maxillule (Figure 9A) outer branch with $4+6$ simple large teeth, a small tooth and a flagelliform seta among the outer group of teeth. Maxilliped (Figure 9B) with distal part of palp without visible transverse suture. Pereopods 1-3 merus and carpus and pereopod 4 merus with a brush of scales on sternal margin of both sexes; pereopod 1 carpus with distinct cleaning device and two rows of strong trifid spines on sternal margin. Pleopods 2-5 exopods with short fine setae on medial margin and some strong spines on outer margin.

Male. - Pereopod 1 (Figure 9C) carpus with spines on sternal margin more numerous than in female. Pereopod 7 (Figure 9D) with no distinct modifications; ischium with sternal margin straight. Genital papilla as in Figure 9E. Pleopod 1 (Figure 9F) exopod cordiform, with no setae along the margin; endopod much longer than exopod, with pointed apical part bent outwards. Pleopod 2 (Figure 9G) exopod triangular, endopod distinctly longer than exopod. Pleopods 3-5 exopods as in Figures 9H-J.

\section{Andricophiloscia pedisetosa n.sp. Figure 10}

\section{Material examined}

\section{Holotype}

1 \%, (WAM C25015), Australia, Western Australia, Murchison Region, Lake Way, site 286 (BES 7207), sample 6, 26 $41.256^{\prime} \mathrm{S}, 120^{\circ} 17.868^{\prime} \mathrm{E}, 21$ May 1999, W.F. Humphreys and H.J. Hahn.

\section{Diagnosis}

A species tentatively ascribed to Andricophiloscia characterized by small size $(2 \mathrm{~mm})$, lack of eyes and pigment, antennule with 3 petaliform aesthetascs, male pereopods with a brush of long setae on carpus and merus, and male pleopod 1 endopod with a styliform apical part bent outwards. 


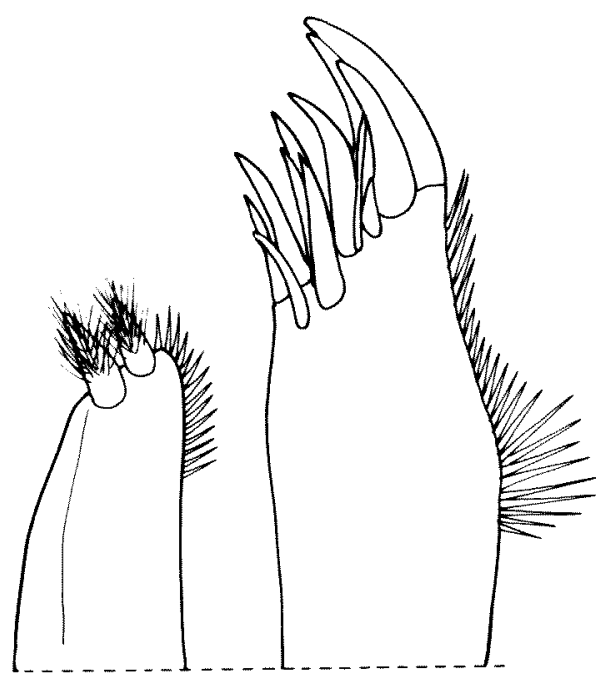

A

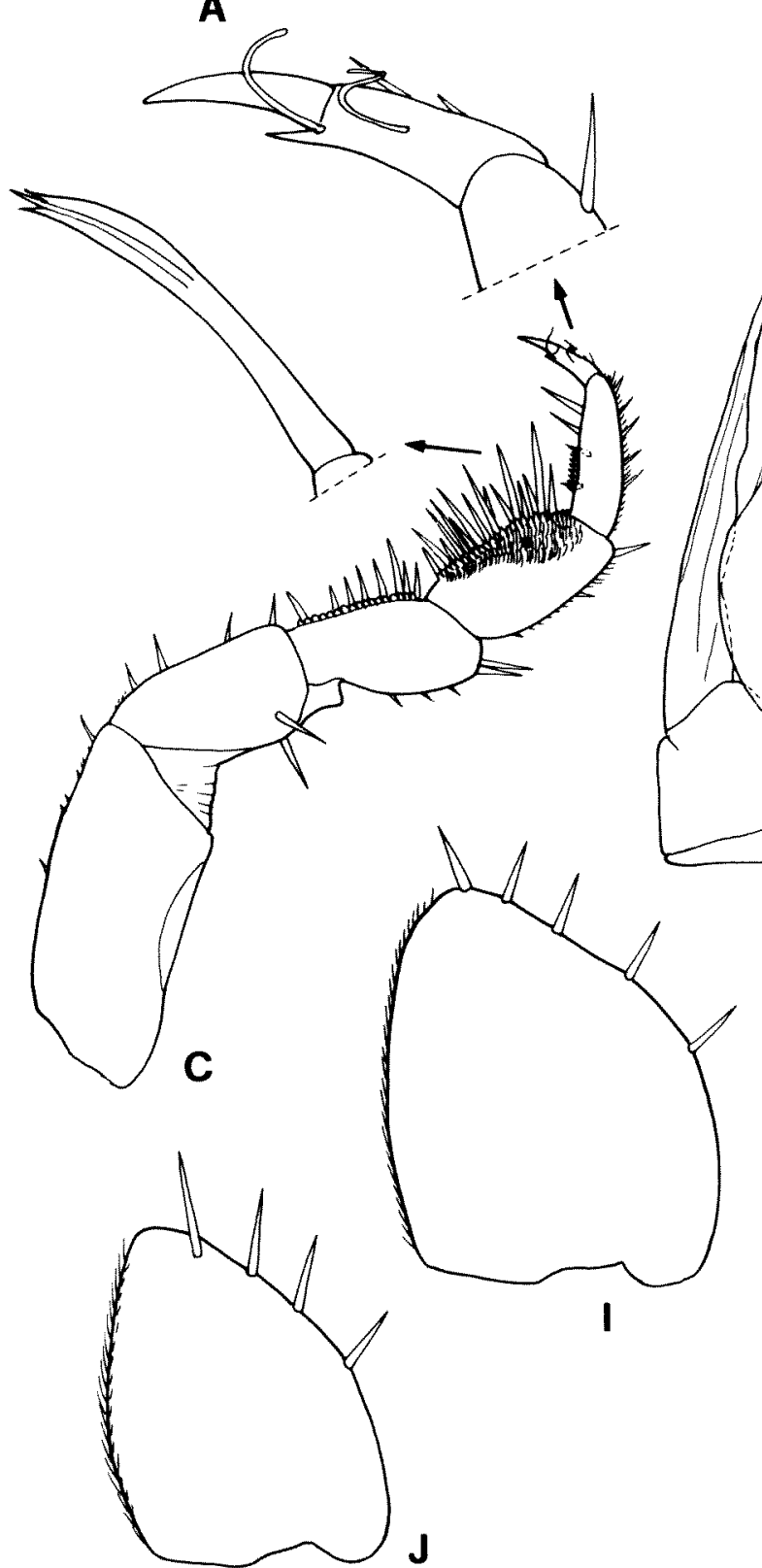

B
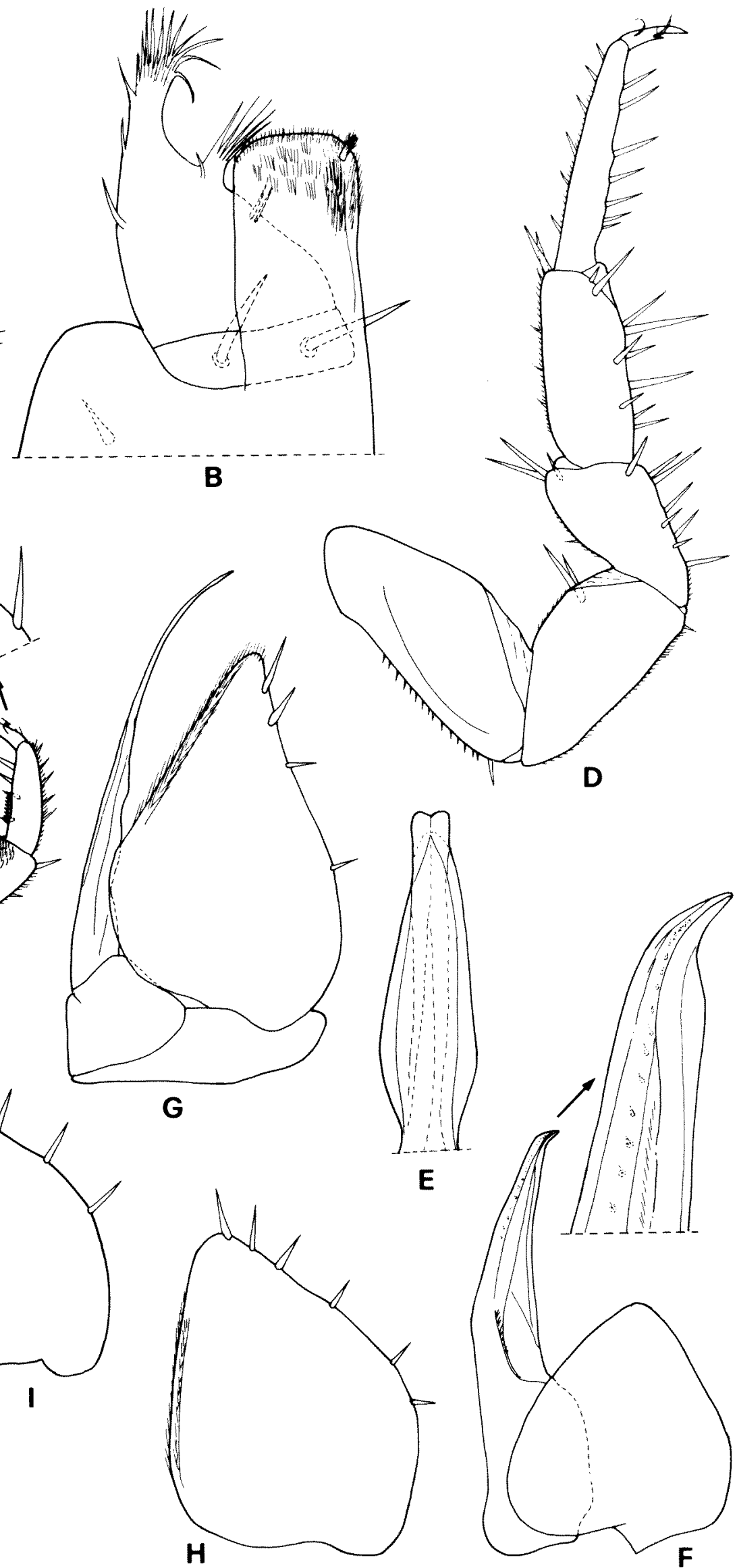

$\mathbf{E}$

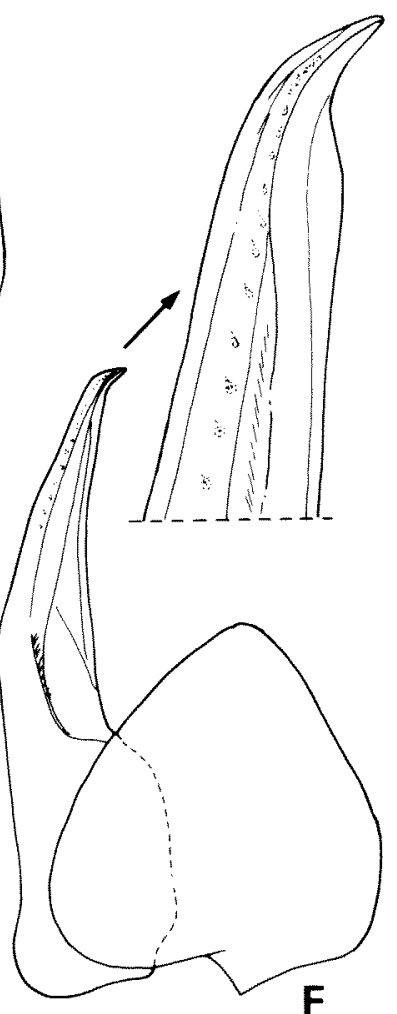

Figure 9 Andricophiloscia stepheni (Nicholls and Barnes, 1926), new specimens from Tenindewa, $\delta$ : A, maxillule; B, maxilliped; C, pereopod 1; D, pereopod 7; E, genital papilla; F, pleopod 1; G, pleopod 2; H, pleopod 3 exopod; I, pleopod 4 exopod; J, pleopod 5 exopod. 


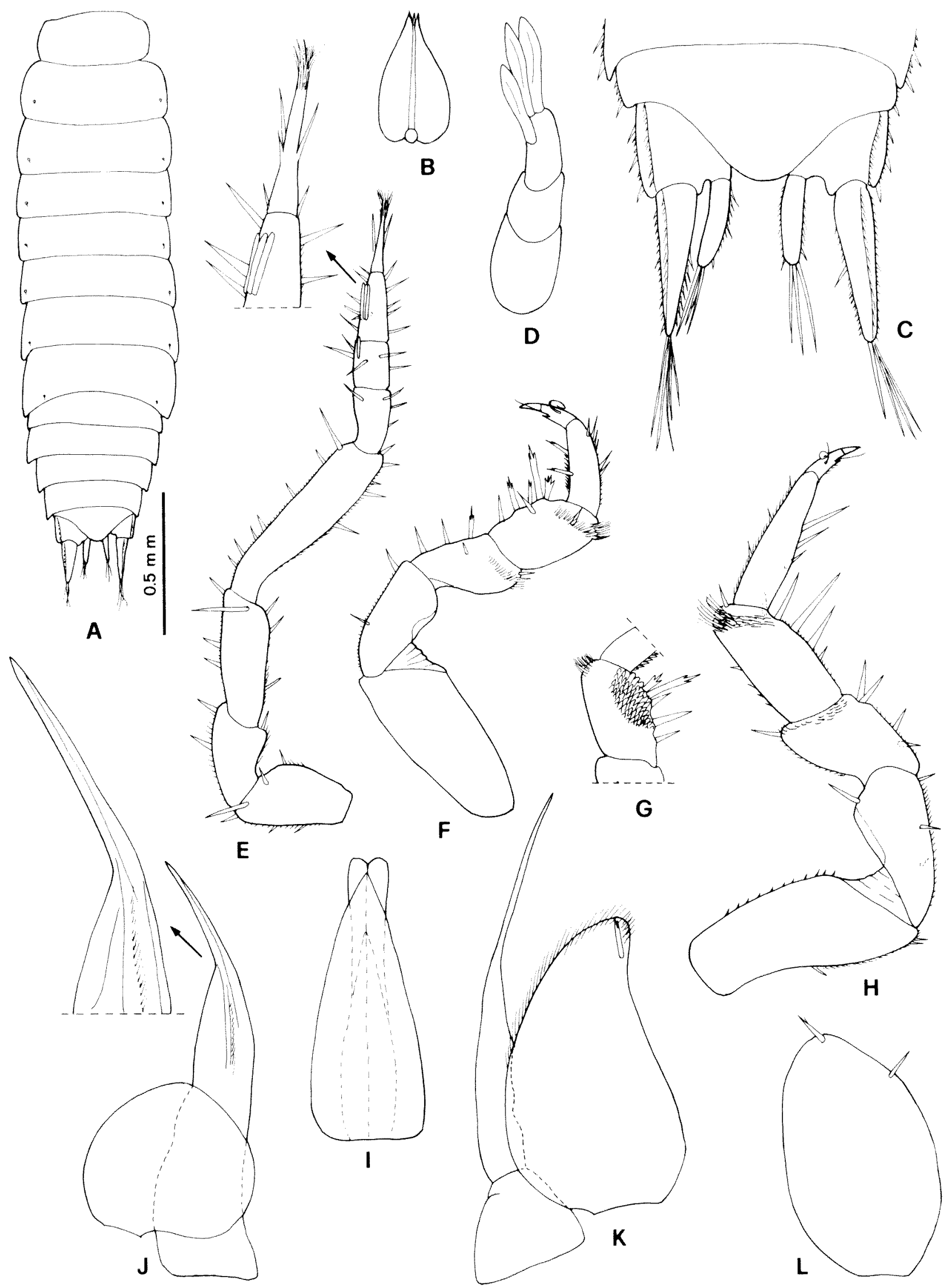

Figure 10 Andricophiloscia pedisetosa sp. nov., holotype $\delta$ : A, whole specimen, dorsal view; B, dorsal scale-spine; C, pleonite 5, telson and uropods, dorsal view; D, antennule; E, antenna; F, pereopod 1, caudal side; G, carpus of pereopod 1, frontal side; $\mathrm{H}$, pereopod 7; I, genital papilla; J, pleopod 1; K, pleopod 2; L, pleopod 5 exopod. 


\section{Description}

Dimensions: $2 \times 0.6 \mathrm{~mm}$. Body colourless, elongate, more than three times as long as wide, with pleon very slightly narrower than pereon (Figure 10A). Dorsum smooth, with some triangular scale-spines (Figure 10B). Noduli laterales distinct disposed more or less at the same distance from lateral margin of pereonites. No gland pores visible on pereonites. Cephalon with no lateral lobes; supra-antennal line regularly bent down in the middle. Eyes absent. Pereonites 1-4 with straight posterior margins and right-angled posterior corners; pereonites 5-7 with posterior corners progressively more acute slightly protruding backwards. Pleonites 3-5 with very small posterior points (Figures 10A, C). Telson (Figure 10C) about twice as wide as long, with concave sides and broadly rounded apex. Antennule (Figure 10D) with articles subequal in length, and two apical and one subapical large petaliform aesthetascs. Antenna (Figure 10E) with fifth article of peduncle as long as flagellum; flagellum with second article shorter than first and third, second and third articles bearing 1 and 3 aesthetascs respectively; apical organ very long, more than third flagellar article. Buccal pieces as in the generic diagnosis. Uropod (Figure 10C) with protopod and exopod deeply grooved on outer margin, insertion of endopod slightly proximal to that of exopod. All pereopods with a brush of long setae on carpus and-to a lesser extent-merus. Pereopod 1 (Figures 10F, G) carpus with some strong trifid setae on sternal margin, cleaning device consisting of a large squamulose area. Pereopod 7 (Figure 10H) with no distinct modifications, ischium with sternal margin slightly convex. Genital papilla as in Figure 10I. Pleopod 1 (Figure 10J) exopod rounded; endopod with styliform apical part slightly bent outwards. Pleopod 2 (Figure 10K) exopod triangular with concave outer margin; endopod distinctly longer than exopod. Pleopods 5 exopod as in Figure 10L.

\section{Remarks}

This tiny new species is only tentatively included in the genus Andricophiloscia. It has all the characters of the generic diagnosis, but it shows also some peculiar features, such as the petaliform aesthetascs of the antennule and the male pereopods (female unknown) with a brush of setae on carpus and merus, which may suggest its belonging to a distinct genus. The absence of eyes may be considered as a mere adaptive character of the species living in an underground environment.

The specimen was collected together with Haloniscus longiantennatus and in the same calcrete system as $H$. stilifer, but it is not certain that this species also has an aquatic way of life. The marginal fringe of fine setae on the exopods of the pleopods present in Haloniscus spp., possibly used for moving in water, are missing in this species, but the same locomotor function could be obtained by the brush of long setae on the pereopods, if this character is not related to sexual dimorphism. Examination of more material with both males and females is needed for a definitive generic assignment of this species and for reliable consideration of its biology.

\section{Etymology}

Latin: pes $=$ foot + setosus $=$ setose. The name refers to the characteristic brush of long setae on carpus of pereopods.

\section{ACKNOWLEDGEMENTS}

Dr Hans J. Hahn provided unstinting and stimulating assistance with the fieldwork near Wiluna. Fieldwork was facilitated by funds from the BankWest Landscope Conservation Visa Card Trust Fund Grants administered by the Department of Conservation and Land Management.

\section{REFERENCES}

Bayly, I.A.E. and Ellis, P. (1969). Haloniscus searlei Chilton: an aquatic 'terrestrial' isopod with remarkable powers of osmotic regulation. Comparative Biochemistry and Physiology 31: 523-528.

Bayly, I.A.E. and Williams, W.D. (1966). Chemical and biological studies on some saline lakes of south-east Australia. Australian Journal of Marine and Freshwater Research 17: 177-228.

Beard, J.S. (1998). Position and development history of the central watershed of the Western Shield, Western Australia. Journal of the Royal Society of Western Australia 81: 157-164.

Blinn, D.W., Blinn, S.L. and Bayly, I.A.E. (1989). Feeding ecology of Haloniscus searlei Chilton, an oniscoid isopod living in athalassic saline waters. Australian Journal of Marine and Freshwater Research 40: 295-301.

Bradbury, J. H. (2000). Western Australian stygobiont amphipods (Crustacea: Paramelitidae) from the Mt Newman and Millstream regions. Records of the Western Australian Museum, Supplement No. 60: 1102.

Bradbury, J.H., and Williams, W.D. (1996). Freshwater amphipods from Barrow Island, Western Australia. Records of the Australian Museum 48: 33-74.

Chilton, C. (1920). On a new isopodan genus (family Oniscidae) from Lake Corangamite, Victoria. Proceedings of the Linnean Society of New South Wales 44: 723-734.

Ellis, P. and Williams, W.D. (1970). The biology of Haloniscus searlei Chilton, an oniscoid isopod living in Australian salt lakes. Australian Journal of Marine and Freshwater Research 21: 51-69.

Green, A.J.A. (1974). IX. Oniscoidea (terrestrial Isopoda). Pp. 229-249 in W.D. Williams (ed.). Biogeography and ecology in Tasmania. Junk, The Hague.

Humphreys, W.F. (1999). Relict stygofaunas living in sea salt, karst and calcrete habitats in arid northwestern 
Australia contain many ancient lineages. Pp. 219-227 in W. Ponder and D. Lunney (eds). The Other 99\%. The Conservation and Biodiversity of Invertebrates. Transactions of the Royal Zoological Society of New South Wales, Mosman.

Humphreys, W.F. (2001). Groundwater calcrete aquifers in the Australian arid zone: the context to an unfolding plethora of stygal biodiversity. Records of the Western Australian Museum, Supplement No. 64: 63-83.

Kroenke, L.W. (1996). Plate tectonic development of the western and southwestern Pacific: mesozoic to present. Pp. 19-34 in A. Keast and S.E. Miller (eds). The origin and evolution of Pacific island biotas, New Guinea to Eastern Polynesia: patterns and processes. Academic Publishing, Amsterdam.

Nicholls, G.E. and Barnes, H.E. (1926). Description of a new species of terrestrial isopod, Haloniscus stepheni, from Western Australia. Journal of the Royal Society of Western Australia 12: 87-96.

Poore, G.C.B. and Humphreys, W.F. (1998). First record of Spelaeogriphacea from Australasia: a new genus and species from an aquifer in the arid Pilbara of Western Australia. Crustaceana 71: 721-742.

Taiti, S. and Ferrara, F. (1986). Taxonomic revision of the genus Littorophiloscia Hatch, 1947 (Crustacea, Isopoda, Oniscidea) with description of six new species. Journal of Natural History 20: 1347-1380.

Taiti, S. and Ferrara, F. (1991). Terrestrial isopods (Crustacea) from the Hawaiian Islands. Bishop Museum Occasional Papers 31: 202-227.
Taiti, S., Ferrara, F. and Iliffe, T.M. (1995). A new species of Haloniscus Chilton, 1920 from New Caledonia (Isopoda, Oniscidea). Crustaceana 68: 321-328.

Vandel, A. (1973a). Les Isopodes terrestres (Oniscoidea) de la Mélanésie. Zoologisches Verhandelingen 125: 1160.

Vandel, A. (1973b). Les Isopodes terrestres de l'Australie. Étude systématique et biogéographique. Mémoires du Muséum National d'Histoire Naturelle, Paris (N.S.) (Série A, Zoologie) 82: 1-171.

Vandel, A. (1977). Les Oniscoides (Isopodes terrestres) de la Nouvelle-Zélande et de l'Archipel Kermadec. Mémoires du Muséum National d'Histoire Naturelle, Paris (N.S.) (Série A, Zoologie) 102: 1-56.

Watts, C.H.S. and Humphreys, W.F. (1999). Three new genera and five new species of Dytiscidae (Coleoptera) from underground waters in Australia. Records of the South Australian Museum 32: 121-142.

Watts, C.H.S. and Humphreys, W.F. (2000). Six new species of Nirridessus and Tjirtudessus (Dytiscidae; Coleoptera) from underground waters in Australia Records of the South Australian Museum 33: 127-144.

Williams, W.D. (1970). Redescription of Haloniscus searlei Chilton, 1920 (Isopoda, Oniscoidea, Oniscidae) from an Australian salt lake. Crustaceana 19: 311-319.

Manuscript received 9 January 2001; accepted 27 February 2001.

Edited by M.S. Harvey. 